\title{
What is Happening to Earnings Inequality and Youth Wages in the 1990s?
}

\author{
by Garnett Picot
}

No. 116

\author{
11F0019MPE No. 116 \\ ISSN: 1200-5223 \\ ISBN: 0-660-17528-0
}

Price: $\$ 5.00$ per issue, $\$ 25.00$ annually

Business and Labour Market Analysis Division

24-F, R.H. Coats Building, Ottawa, K1A 0T6

Statistics Canada (613) 951-8214

Facsimile Number: (613) 951-5403

The paper is available on Internet: (www.statcan.ca)

\section{July 1998}

This paper extends earlier work published in the Canadian Business Economics in the fall of 1997. The author thanks Wendy Pyper for her usual excellent research assistance in preparing this paper.

This paper represents the views of the author and does not necessarily reflect the opinions of Statistics Canada. 



\section{Table of Contents}

I. Introduction 1

II. The Data, Time Frame and Measures of Earnings Dispersion___ 2

III. Inequality and Polarization Trends Among Paid Workers___ 4

IV. Inequality and Polarization Trends Among the Working Age Population _ 14

V. The Rising Earnings Differential Between the Young and the Old: Is it Wages or Hours Based? 20

VI. Conclusion —25

Selected References __ 33 



\section{Abstract}

The increase in earnings inequality among men in particular in Canada has been well documented. This paper adds to our knowledge of inequality trends by addressing three issues. First, what has happened to earnings inequality among the employed population in the 1990s? We find that earnings inequality and polarization increased little in the population of all workers (men and women combined) between the mid-1980s and mid-1990s. The second question relates to the impact of the changing propensity of Canadians to hold a job on earnings inequality. Put another way, if we focus on the entire population of working age Canadians (those with and without paid employment), what are the inequality trends. We find that earnings inequality among the working age population changed little over the 1980s and 1990s. This analysis incorporates both the influence of the changing employment/population ratio and inequality trends among employed workers on overall earnings inequality among the working age population. But this relative stability in overall earnings inequality since the mid-1980s masks a number of offsetting underlying trends. Some groups of workers are making earnings gains (notably older workers, and women) while others are losing (notably younger workers and men). This paper focuses in particular on the earnings trends among younger workers, and finds that the decline in annual earnings of younger male workers in particular is associated with a decline in real hourly wages.

Key words: Earnings inequality, youth wages, polarization 



\section{Introduction}

The increasing inequality of employment earnings particularly among men during the 1980s has been well documented (Myles, Picot and Wannell, 1988; The Economic Council of Canada, 1991; Morissette, Myles and Picot, 1994; Burbidge, Magee and Robb, 1993; Beach and Slotsve, 1994; Richardson, 1994). Various dimensions of this rising polarization of earnings have also been explored, including the declining real and relative wages of young workers (Davis, 1992; Betcherman and Morissette, 1994), and the relative stability of the education wage premium in Canada as compared to the US (Freeman and Needels 1991; Bar-Or et al., 1993; Morissette, Myles, and Picot, 1994).

It is now commonly accepted that earning inequality, or if you wish, the earnings gap between low and high wage workers, has increased in Canada through the 1980s. This is in contrast to inequality trends in family income ${ }^{1}$, which have changed little (Beach and Slotsve, 1996). This paper updates and adds to the earnings inequality story by addressing three issues:

(1) What has happened to the inequality of annual earnings among all paid workers-men and women combined-in Canada during the 1990s? Labour market trends have been very different for men and women, justifying the separate analysis of these groups. Hence, many studies report the results for men and women separately (e.g. Beach and Slotsve, 1996), and the continued increase in earnings inequality among males is noted. But much of the inequality story relates to the offsetting trends between men and women, and this aspect is lost if the focus is not on all workers. Others have observed that earnings inequality and polarization among all paid workers have risen only slowly (Wolfson, 1996b) or not at all over the late 1980s and early 1990s (Zyblock, 1996a). The OECD (1996) found that, based on full-time fullyear workers, inequality in annual earnings has not increased since the mid-1980s.

We find that earnings inequality and polarization increased little if at all among all paid workers between the mid-1980s and mid-1990s. In the aggregate, the manner in which the labour market is distributing annual earnings has changed relatively little during the past decade. This is at odds with the general perception that inequality and polarization continue to increase. But this is the result of a number of offsetting trends, some of which are quite significant, and should not be lost sight of. There was an increase in earnings inequality among all male workers over the period. The real earnings of lower paid males fell $13 \%$ over the 1980s, and $9 \%$ between the mid-1980s and mid-1990s. Earnings of higher paid males rose over the same period. Among women earnings inequality changed little between the mid-1980s and mid-1990s.

(2) What is the impact of the changing pattern of job holding on earnings inequality and polarization? This is done by extending the analysis to include all persons of working age. Focusing only on paid workers (those holding jobs) excludes one important aspect of labour market change: the changing propensity of persons of working age to be employed. The manner in which the labour market is distributing earnings is not only influenced by changing hours of work and hourly wages among those who are working, but also by the share of the population that holds a job. If the distribution of earnings among employed workers remains

1 Which includes income not only from employment earnings but income from other sources as well, such as government transfers, investments, pensions, etc. 
unchanged through time, but the proportion of the population with jobs falls, would earning inequality increase? Earnings would be more highly concentrated among fewer people (the remaining job holders). In that sense inequality would have increased. The converse can occur if the employment/population ratio rises rather than falls over time. To include the effects of changes in employment patterns on inequality, the goal of this section, it is necessary to move beyond paid workers and include persons of working age with zero earnings.

We find that earnings inequality and polarization among the working age population changed relatively little over the 1980s and early 1990s. If anything, there was a decline in polarization during the 1980s, and stability in the 1990s. The decline during the 1980s was related to the rising female employment/population ratio. This overall stability is the result of offsetting trends: a rise in earnings inequality among males, and a decline among women.

If inequality/polarization has changed little in the past decade, why all the concern about this issue? This apparent stability masks dramatic changes in the labour market which have been observed for some time. There have been significant changes in the real and relative earnings of various groups. As is well known, among workers as a whole, average annual earnings have changed little over the 1980s and 1990s. But the real earnings of men with low earnings and low skill levels have fallen dramatically (e.g. Kuhn and Robb, 1996), as have those of younger workers (under age 35), particularly men (e.g. Morissette, Myles and Picot, 1994). Counteracting these declines have been real gains in the earning of most groups of women, both low paid and high paid, higher paid males, and of older workers. The annual earnings of men remain above those of women, however.

(3) Does the decline in the earnings of the young continues in the 1990s, and is it driven by falling hourly wage rates or changes in relative working time? The polarization in hours worked has played a significant role in the change in earnings inequality (Morissette, Myles and Picot, 1994; Morissette, 1995). Has there been a relative price or quantity adjustment among younger workers?

This work suggests that much of the decline in the real annual earnings of the young (men in particular) occurred in and around the 1981-82 recession. Their earnings did not recover during the economic expansion, and fell again during the 1990s, however. But unlike the story for the population as a whole, this decline is related largely to declining hourly wages, not changing relative hours worked. There has been a downward shift in the real hourly wages of young people.

\section{The Data, Time Frame and Measures of Earnings Dispersion}

Data from the Survey of Consumer Finances (SCF) for selected years between 1975 and 1995 are used in this work. The results are produced for three different populations including: (1) all those between the ages of 17 and 64 with paid employment (including all persons with positive wages and salaries from paid employment, but excluding persons with self-employment earnings), (2) paid employees working full-time full-year, and (3) all persons in the working age population (i.e. between the ages of 17 and 64) whether they had positive earnings or not.

Trends in inequality measures for these population groups are shown for most years between 1977 and 1995. In many cases the measures of dispersion are shown for all years. However, earnings inequality varies significantly over the business cycle. Therefore, years were selected in this 
analysis that were roughly comparable with respect to unemployment rates, as we are interested in longer term structural change, not cyclical variation. Hence, the results are presented for three periods (1) 1981 to 1989, years with the lowest unemployment over the cycle, (2) 1984 to 1993, years just after the cyclical troughs, and (3) 1986 and 1995, which allows the inclusion of the latest data point. In terms of unemployment, these pairs of years are almost identical. Unemployment was at $7.6 \%$ and $7.5 \%$ respectively in 1981 and 1989 , and at $11.3 \%$ and $11.2 \%$ respectively in 1984 and 1993 , and $9.6 \%$ and $9.5 \%$ in 1986 and 1995 .

Changes in the dispersion of earnings are assessed using three different types of measures: (1) aggregate inequality indexes, (2) polarization measures that indicate the change in the distribution of workers by earnings level, and (3) indexes indicating the change in real earnings among workers at the bottom, middle and top of the earnings distribution.

There are numerous summary measures of inequality. Three inequality measures are used here. They have been selected because they are applicable to both employed workers and persons with zero earnings. ${ }^{2}$ They are the well-known gini coefficient, the (squared) coefficient of variation (CV) and an exponential measure. Each of these is sensitive to change in a particular part of the earnings distribution, and hence together they provide a more comprehensive picture than using one alone. The gini is sensitive to changes in the middle of the distribution, the CV to changes at the top, and the exponential to changes at the bottom. For more information see Wolfson (1996b). In virtually all cases all three measures produce the same general result. In the interest of brevity only the gini is shown in the main body of the report. The other results are provided in an appendix.

The polarization measure used is simply the change in the share of workers in ten earnings categories. This allows one to assess whether the proportion of workers at the bottom and top have been increasing, while the share in the middle is declining. A Foster-Wolfson polarization index is also employed. Some commonly used polarization measures, such as the ratio of earning in the top decile to those in the bottom are not used because they are not applicable to the entire working age population. ${ }^{3}$

Aside from inequality and polarization measures, an often more informative way of assessing inequality trends is to focus directly on change in real annual earnings of workers at the top and bottom of the distribution. The issue in inequality debates is often the extent to which real (and relative) earnings of workers at the bottom of the distribution have fallen. The story starts by examining trends in real earnings, with the CPI used as a deflator.

2 Many inequality measures require the logarithm of earning to be computed in the formula. If a worker has zero earnings, this term is undefined, as the log of zero is infinity. To prevent this, we relied on measures that do not include a log (earnings) term.

3 Polarization measures such as the ratio of earning in the top to bottom deciles are not applicable because a very large proportion of workers at the bottom of the distribution are all at the same position in the distribution.. i.e. at zero earnings. There is little change at the bottom of the distribution, so measures focusing on the bottom...such as the D9/D1 are not informative. As well, they are undefined since one would be dividing by zero. 


\section{Inequality and Polarization Trends Among Paid Workers}

\section{Changes in Real Earnings Among all Paid Workers}

When studying trends in the dispersion of earnings, the change in real earnings of lesser and higher workers is of central importance. Earnings inequality may be rising during a period when everyone's real earnings are increasing. Both the rich and the poor are getting richer. That is a very different situation than one where inequality is rising because real earnings among lower paid workers is falling, while among the higher paid rising. The rich are getting richer, the poor poorer.

For example, it is well known that the real earnings of lower paid males have been falling dramatically, while the earnings of higher paid male workers have been rising. Changes in real earnings patterns are behind the trends in inequality and polarization, and hence we focus on these trends first. A number of points become evident:

- Among paid workers as a whole (men and women combined), there is little evidence that the earnings of workers at the bottom of the distribution fell, while those of others increased. Growth in annual earnings at the bottom of the distribution is very cyclically sensitive (appendix Chart A-1). Comparisons among recessionary and expansionary years can be very misleading. Using the year combinations with similar unemployment rates outlined earlier, however, there is little indication that earnings growth among workers at the bottom of the distribution was significantly different from that of workers in the middle or top of the distribution (Chart 1, Table 1). Between the first two sets of years (81 and 89, 84 and 93) the growth rate in earnings among all workers in the bottom two deciles was above the growth rate for paid workers as a whole. Between the mid-1980s and mid-1990s, it was marginally lower. There is little evidence that the earnings of workers at the bottom of the distribution increased more slowly than other workers (or declined)

- This contrasts with the view one gets if one simply picks the end points of the periods and ignores cyclical variation. Between 1981 and 1995 average earnings were virtually unchanged, but those in the bottom half of the distribution fell by between $3.5 \%$ and $11.4 \%$ (depending upon the decile), while those in the top two deciles rose by $1.0 \%$ and $5.5 \%$, clear evidence of an increase in the dispersion of earnings. There are probably two reasons for this. First, these years are in different parts of the cycle. Secondly, however, earnings in the bottom decile did fall between 1994 and 1995. This is a part of the business cycle where one would expect to see earnings for this group rising. This was reflected in the low-income data, as the incidence of low-income rose in 1995, a year where one expects it to be falling because it is an expansionary phase of the cycle, although economic growth was quite weak. Thus, changes may have taken place in 1995 that influenced this outcome. 


\section{Chart 1: Percent Change in Annual Earnings, by Decile, Men \& Women,}

All Employed Persons
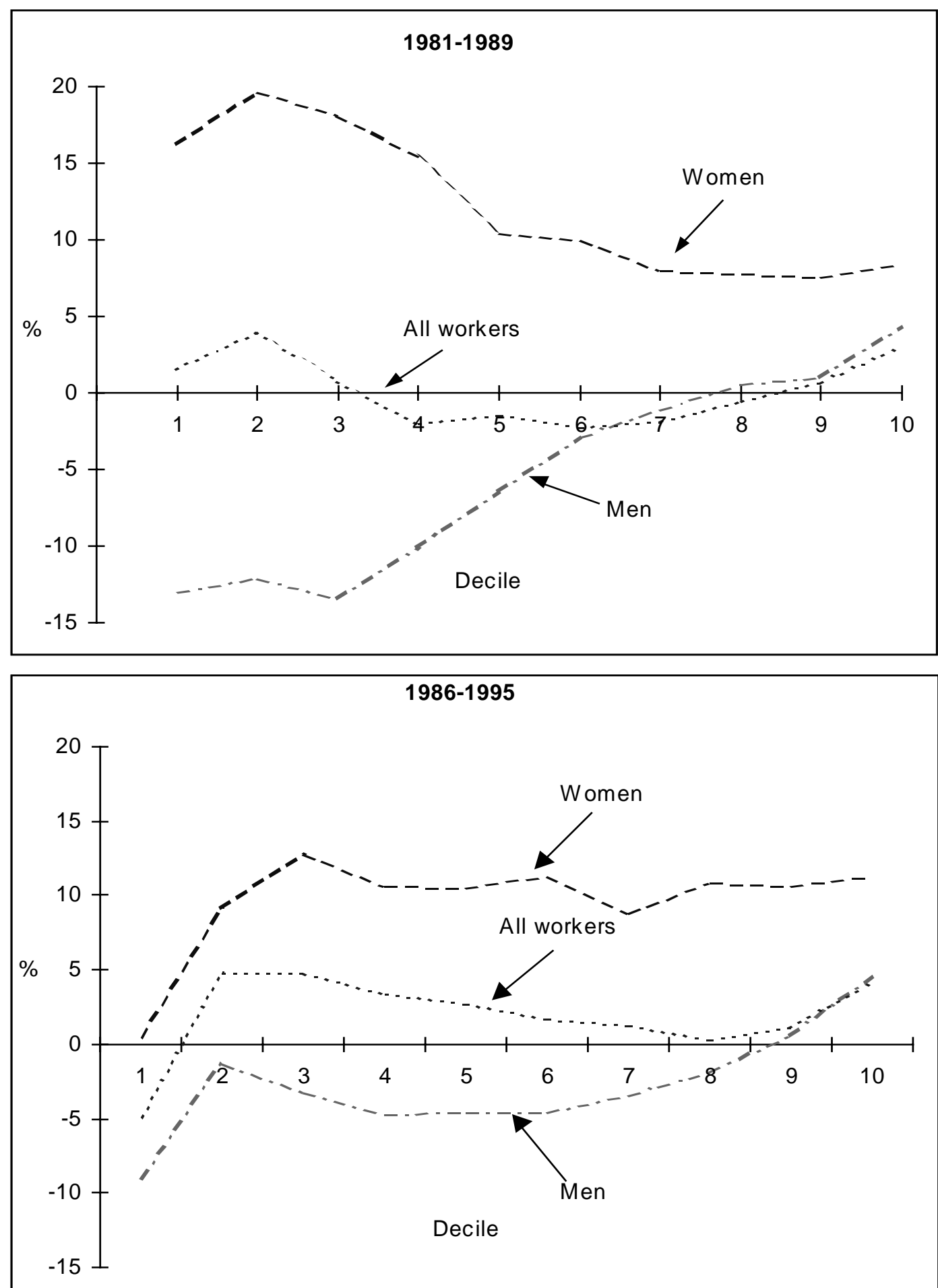
Table 1: Percent Change in Real Annual Earnings Between Selected Years, by Decile, All Paid Workers

\begin{tabular}{|c|c|c|c|c|c|c|c|}
\hline \multicolumn{3}{|c|}{ Men and Women } & \multirow[b]{2}{*}{$\begin{array}{c}\text { Earnings } \\
\text { in } 1984 \\
(\$ 1993) \\
(000 s)\end{array}$} & \multirow[b]{2}{*}{$\begin{array}{l}\text { \% Change } \\
84-93\end{array}$} & \multirow[b]{2}{*}{$\begin{array}{c}\text { Earnings } \\
\text { in } 1986 \\
(\$ 1993) \\
(000 s) \\
\end{array}$} & \multirow[b]{2}{*}{$\begin{array}{c}\text { \% Change } \\
86-95\end{array}$} & \multirow[b]{2}{*}{$\begin{array}{c}\text { \% Change } \\
81-95\end{array}$} \\
\hline Decile & $\begin{array}{c}\text { Earnings } \\
\text { in } 1981 \\
(\$ 1993) \\
(000 s) \\
\end{array}$ & \begin{tabular}{c|c} 
\% Change & 1 \\
$81-89$ & \\
\end{tabular} & & & & & \\
\hline 1 & $\$ 2.0$ & $+1.5 \%$ & $\$ 1.6$ & $+6.6 \%$ & $\$ 1.9$ & $-4.9 \%$ & $-11.4 \%$ \\
\hline 2 & $\$ 5.5$ & $+4.0 \%$ & $\$ 4.8$ & $+4.2 \%$ & $\$ 5.3$ & $+4.8 \%$ & $-4.1 \%$ \\
\hline 3 & $\$ 10.5$ & $+0.8 \%$ & $\$ 8.9$ & $+1.8 \%$ & $\$ 9.5$ & $+4.8 \%$ & $-5.0 \%$ \\
\hline 4 & $\$ 15.8$ & $-2.0 \%$ & $\$ 13.7$ & $+2.9 \%$ & $\$ 14.5$ & $+3.4 \%$ & $-5.4 \%$ \\
\hline 5 & $\$ 20.9$ & $-1.4 \%$ & $\$ 18.8$ & $+2.7 \%$ & $\$ 19.7$ & $+2.7 \%$ & $-3.5 \%$ \\
\hline 6 & $\$ 25.8$ & $-2.2 \%$ & $\$ 24.1$ & $+2.4 \%$ & $\$ 24.9$ & $+1.7 \%$ & $-2.0 \%$ \\
\hline 7 & $\$ 31.2$ & $-1.9 \%$ & $\$ 29.8$ & $+2.0 \%$ & $\$ 30.3$ & $+1.2 \%$ & $-1.7 \%$ \\
\hline 8 & $\$ 37.3$ & $-0.5 \%$ & $\$ 36.2$ & $+1.7 \%$ & $\$ 37.1$ & $+0.3 \%$ & $-0.2 \%$ \\
\hline 9 & $\$ 45.4$ & $+0.6 \%$ & $\$ 44.4$ & $+2.8 \%$ & $\$ 45.3$ & $+1.1 \%$ & $+1.0 \%$ \\
\hline 10 & $\$ 65.3$ & $+3.0 \%$ & $\$ 63.1$ & $+7.2 \%$ & $\$ 66.1$ & $+4.2 \%$ & $+5.5 \%$ \\
\hline All Deciles & $\$ 26.0$ & $+0.2 \%$ & $\$ 24.5$ & $+3.7 \%$ & $\$ 25.5$ & $+2.3 \%$ & $+0.1 \%$ \\
\hline \multicolumn{3}{|l|}{$\overline{\text { Men }}$} & \multirow[b]{2}{*}{\begin{tabular}{|c|c} 
earnings \\
in 1984 \\
$(\$ 1993)$ \\
$(000 s)$
\end{tabular}} & \multirow[b]{2}{*}{$\begin{array}{c}\text { \% Change } \\
84-93\end{array}$} & \multirow[b]{2}{*}{\begin{tabular}{|c|c|} 
Earnings \\
in 1986 \\
$(\$ 1993)$ \\
$(000 s)$ \\
\end{tabular}} & \multirow[b]{2}{*}{$\begin{array}{c}\text { \% Change } \\
86-95\end{array}$} & \multirow[b]{2}{*}{\begin{tabular}{|c|} 
\% Change \\
$81-95$
\end{tabular}} \\
\hline Decile & $\begin{array}{c}\text { Earnings } \\
\text { in } 1981 \\
(\$ 1993) \\
(000 s) \\
\end{array}$ & $\begin{array}{l}\text { \% Change } \\
\text { 81-89 }\end{array}$ & & & & & \\
\hline 1 & $\$ 3.3$ & $-13.0 \%$ & $\$ 2.0$ & $-0.2 \%$ & $\$ 2.4$ & $-9.0 \%$ & $-31.7 \%$ \\
\hline 2 & $\$ 9.7$ & $-12.1 \%$ & $\$ 6.4$ & $-3.2 \%$ & $\$ 7.4$ & $-1.3 \%$ & $-24.5 \%$ \\
\hline 3 & $\$ 17.0$ & $-13.4 \%$ & $\$ 12.5$ & $-4.1 \%$ & $\$ 13.8$ & $-3.2 \%$ & $-21.6 \%$ \\
\hline 4 & $\$ 23.7$ & $-10.1 \%$ & $\$ 19.1$ & $-4.0 \%$ & $\$ 20.5$ & $-4.7 \%$ & $-17.7 \%$ \\
\hline 5 & $\$ 29.2$ & $-6.5 \%$ & $\$ 25.7$ & $-3.3 \%$ & $\$ 26.9$ & $-4.6 \%$ & $-12.3 \%$ \\
\hline 6 & $\$ 34.0$ & $-2.9 \%$ & $\$ 31.8$ & $-2.5 \%$ & $\$ 32.6$ & $-4.6 \%$ & $-8.5 \%$ \\
\hline 7 & $\$ 38.8$ & $-1.1 \%$ & $\$ 37.3$ & $-0.8 \%$ & $\$ 38.3$ & $-3.5 \%$ & $-4.7 \%$ \\
\hline 8 & $\$ 44.4$ & $+0.5 \%$ & $\$ 43.2$ & $+0.5 \%$ & $\$ 44.3$ & $-1.9 \%$ & $-2.2 \%$ \\
\hline 9 & $\$ 52.2$ & $+1.0 \%$ & $\$ 50.9$ & $+2.6 \%$ & $\$ 52.2$ & $+0.6 \%$ & $+0.5 \%$ \\
\hline 10 & $\$ 73.2$ & $+4.3 \%$ & $\$ 70.2$ & $+9.3 \%$ & $\$ 74.4$ & $+4.6 \%$ & $+6.2 \%$ \\
\hline All Deciles & $\$ 32.6$ & $-1.7 \%$ & $\$ 29.9$ & $+1.5 \%$ & $\$ 31.3$ & $-0.9 \%$ & $-4.8 \%$ \\
\hline \multicolumn{3}{|l|}{ Women } & \multirow{2}{*}{\begin{tabular}{|c|c} 
& \\
$\mathrm{e}$ & $\begin{array}{c}\text { Earnings } \\
\text { in } 1984 \\
(\$ 1993) \\
(000 s)\end{array}$ \\
&
\end{tabular}} & \multirow[b]{2}{*}{\begin{tabular}{|c|}
$\%$ Change \\
$84-93$
\end{tabular}} & \multirow[b]{2}{*}{\begin{tabular}{|c|} 
Earnings \\
in 1986 \\
$(\$ 1993)$ \\
$(000 s)$ \\
\end{tabular}} & \multirow[b]{2}{*}{$\begin{array}{c}\text { \% Change } \\
86-95\end{array}$} & \multirow[b]{2}{*}{\begin{tabular}{|c} 
\% Change \\
$81-95$
\end{tabular}} \\
\hline Decile & $\begin{array}{c}\text { Earnings } \\
\text { in } 1981 \\
(\$ 1993) \\
(000 s) \\
\end{array}$ & $\begin{array}{l}\text { \% Change } \\
\text { 81-89 }\end{array}$ & & & & & \\
\hline 1 & $\$ 1.3$ & $+16.2 \%$ & $\$ 1.2$ & $+15.3 \%$ & $\$ 1.5$ & $+0.4 \%$ & $+9.8 \%$ \\
\hline 2 & $\$ 3.8$ & $+19.7 \%$ & $\$ 3.6$ & $+13.2 \%$ & $\$ 4.1$ & $+9.1 \%$ & $+17.1 \%$ \\
\hline 3 & $\$ 6.7$ & $+18.1 \%$ & $\$ 6.6$ & $+9.1 \%$ & $\$ 6.9$ & $+12.8 \%$ & $+17.5 \%$ \\
\hline 4 & $\$ 10.1$ & $+15.4 \%$ & $\$ 10.0$ & $+10.1 \%$ & $\$ 10.4$ & $+10.6 \%$ & $+13.6 \%$ \\
\hline 5 & $\$ 14.1$ & $+10.4 \%$ & $\$ 13.6$ & $+11.3 \%$ & $\$ 14.2$ & $+10.5 \%$ & $+11.9 \%$ \\
\hline 6 & $\$ 17.9$ & $+10.0 \%$ & $\$ 17.7$ & $+11.7 \%$ & $\$ 18.2$ & $+11.3 \%$ & $+13.4 \%$ \\
\hline 7 & $\$ 21.7$ & $+8.0 \%$ & $\$ 21.8$ & $+10.4 \%$ & $\$ 22.7$ & $+8.8 \%$ & $+13.7 \%$ \\
\hline 8 & $\$ 25.6$ & $+7.8 \%$ & $\$ 26.2$ & $+11.0 \%$ & $\$ 26.7$ & $+10.8 \%$ & $+16.1 \%$ \\
\hline 9 & $\$ 31.4$ & $+7.5 \%$ & $\$ 32.3$ & $+11.4 \%$ & $\$ 33.2$ & $+10.6 \%$ & $+17.0 \%$ \\
\hline 10 & $\$ 45.8$ & $+8.5 \%$ & $\$ 46.6$ & $+13.3 \%$ & $\$ 48.5$ & $+11.3 \%$ & $+17.9 \%$ \\
\hline All Deciles & $\$ 17.8$ & $+9.5 \%$ & $\$ 18.0$ & $+11.7 \%$ & $\$ 18.6$ & $+10.6 \%$ & $+15.7 \%$ \\
\hline
\end{tabular}


- If the analysis is restricted to full-time full-year workers, as is often done to exclude the effect of changing patterns of part-time work, then workers with lower earnings do fare worse then their wealthier counterparts during the $1980 \mathrm{~s} .{ }^{4}$ Even among these workers, however, real earnings rose faster among lower paid workers than among other workers during the mid-1980s to mid1990s. This suggests that earnings trends had changed significantly between the 1980s and 1990s. But what if we focus on men and women separately.

- Among men the rich are getting richer, the poor poorer. The familiar pattern of dramatic declines in real earnings among lower paid workers with increases among higher paid workers is observed. This occurred during all three periods, and in dramatic fashion. Over the 1980s earnings among employed men in the bottom three deciles fell by around $13 \%$, while rising by $1.0 \%$ and $4.3 \%$ in the top two deciles (Chart 1, Table 1). A similar story is observed over the 1986 to 1995 period, when earnings among men in the bottom decile fell by $9 \%$, while rising $5 \%$ among those at the top.

- Employed women, on the other hand, saw their real earnings increase in virtually all parts of the distribution. There have been substantial increases in the earnings of women at the bottom of the distribution, particularly during the 1990s. The real earnings of women in the bottom half of the distribution rose $10 \%$ to $20 \%$ over the 1980 s, and from $0 \%$ to $13 \%$ between the mid-1980s and mid-1990s. Earlier work has shown that these increases are largely associated with increasing number of weeks worked (Morissette, Myles, Picot, 1994).

This increase in female earnings contributed to the stability in the earnings inequality of all workers. It offset a decline in earnings among men in all segments of the earnings distribution except at the very top (where earnings among both men and women rose). The end result is that earnings trends among all workers that were not that dissimilar across the ten deciles (Chart 1). It must be remembered, however, that even though women experienced earnings gains and lower paid men experienced earnings losses in the 1980s, annual earnings are still substantially higher for men than women. In 1995 , men in the top decile had average earnings of $\$ 78,000$, women $\$ 54,000$; in the bottom decile men earned an average $\$ 2,200$, women $\$ 1,500$, (in 1993 dollars).

\section{Earnings Inequality Trends Among Paid Workers}

The earnings trends just described are reflected in the earnings inequality measures. Among all paid workers ${ }^{5}$, aside from cyclical fluctuations, inequality has risen only slowly if at all over the late 1980s and early 1990s. Chart 2 and Table A-1 show the gini coefficient for most years. This is the most commonly used measure of earnings inequality. The cyclical variation is quite evident. When the three inequality measures are compared for two sets of years (1981 and 1989, 1984 and 1993) they are seen to rise only $1 \%$ to $3 \%$, a very small change over an eight or nine year period. There is also little change over the latest period. From 1986 to 1995, two years with comparable unemployment rates at around $9.5 \%$, the gini is virtually unchanged at around .418. While little

4 Data not reported here indicate that for full-time full-year workers (men and women combined) real annual earnings fell around $8 \%$ in the bottom two deciles, while declining $1 \%$ overall, and increasing $2 \%$ in the top two deciles between 1981 and 1989. During the 1986-95 period, however, earnings in the bottom four deciles rose between $2 \%$ and $20 \%$, compared to a $3.7 \%$ increase overall, and a $1 \%$ to $5 \%$ increase in the top four deciles.

5 The population includes all persons aged 17-64 with positive wages and salaries. It excludes persons with selfemployment earnings. 
change is observed for the population of all workers, inequality among male workers appears to have risen significantly over the period, while among women little change is observed (Chart 2). The same general trends are observed using the two other measures employed here, the exponential and the CV (see appendix Chart A-2). But comparisons over time are difficult because of the cyclical variation.

\section{Controlling for Cyclical Variation in the Gini Measure}

A more satisfactory approach to establishing long term trends in inequality is to control for cyclical variation in the gini measure, and then ask if inequality has risen. This is done using a two step procedure. The unemployment rate is used as the cyclical indicator. The association between the cyclical variation in the unemployment rate and inequality measures has been noted in other work (e.g. Beach and Slotsve, 1996). But the unemployment rate itself has experienced a long-term rise, and it is only the cyclical variation in the unemployment rate that is of interest here. We do not want to exclude the impact of a long-term rise in unemployment on inequality, just the effect of the cyclical variation in the rate. Hence, we first extract the longer term time trend from the unemployment rate. The remaining variation in the rate reflects the cyclical variation, which is then used to control for cyclical variation in the gini. This is done by regressing the gini on the variable reflecting the cyclical variation in the unemployment rate, regional dummies, and yearly dummies. This equation is used to calculate the gini coefficient with cyclical variation removed. Details are given below. ${ }^{6}$

The results (Chart 3) indicate that among all paid workers, inequality rose to 1983, and has remained constant since that time. Among men, earnings inequality has been rising more or less constantly since 1977, the earliest year in these data, although there appears to have been a levelling since 1992. The gini (with cyclical variation removed) rose approximately $18 \%$ (from .331 to .390) between 1977 and the early 1990s. This trend is well known, and is of concern because of the substantial declines in the real earnings of lower paid, and presumably lower skilled, male workers. Among all employed women inequality is seen to rise to the early 1980s, and then stabalize.

\section{Earnings Polarization Trends Among Paid Workers}

If workers are increasingly polarized to the bottom and top of the earnings distribution, this is not necessarily the same as rising earnings inequality. They are two different concepts with their own measures. Essentially, inequality measures are concerned with changes in the share of earnings received by persons in different parts of the distribution. If earnings are transferred such that the share of earnings of someone in the bottom of the distribution rises and that of someone in the top

6 The long-term time trend in the unemployment rate is determined by regressing the unemployment rate on a quadratic time trend. This is done for the five regions in Canada using data from 1977 to 1996. The time variables are significant in most cases (Table A-2). The residuals ( the difference between the estimated and actual unemployment rate in any given year) are used as the measure of the cyclical fluctuation in unemployment, with the long-term time trend removed. The gini coefficient (for each region and year) is then regressed on the unemployment rate residual, five region dummies, and a dummy variable for each year between 1976 and 1995 (results in Table A-3). The yearly dummy variables indicate the time trend in the gini, after controlling for cyclical variation as indicated by the residual unemployment rates. The residual unemployment rate variable is statistically significant as one would expect, since inequality rises in recessions. To compute the gini with the cyclical variation removed, we simply set the cyclical unemployment rate variable to zero, and calculated the annual values of the gini as indicated by the yearly dummies. The coefficient used for the five regions was the weighted value of the five coefficients, with the weight being the region's share of total employment in Canada. 


\section{Chart 2: Gini Coefficient, Paid Employees, 1975-1995}

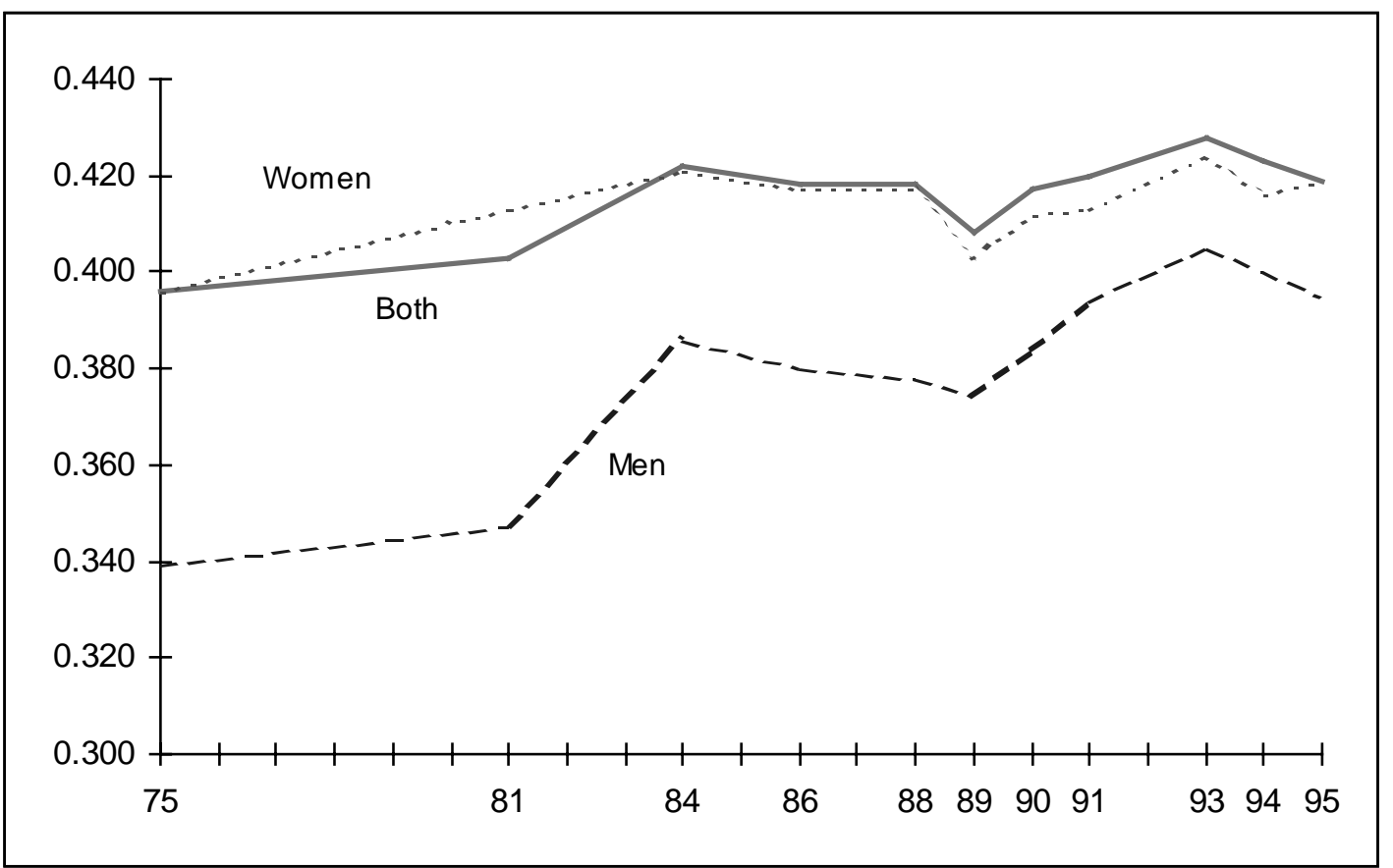

\section{Chart 3: Gini Coefficient with Cyclical Variation Removed, 1977-95, Paid Employees}

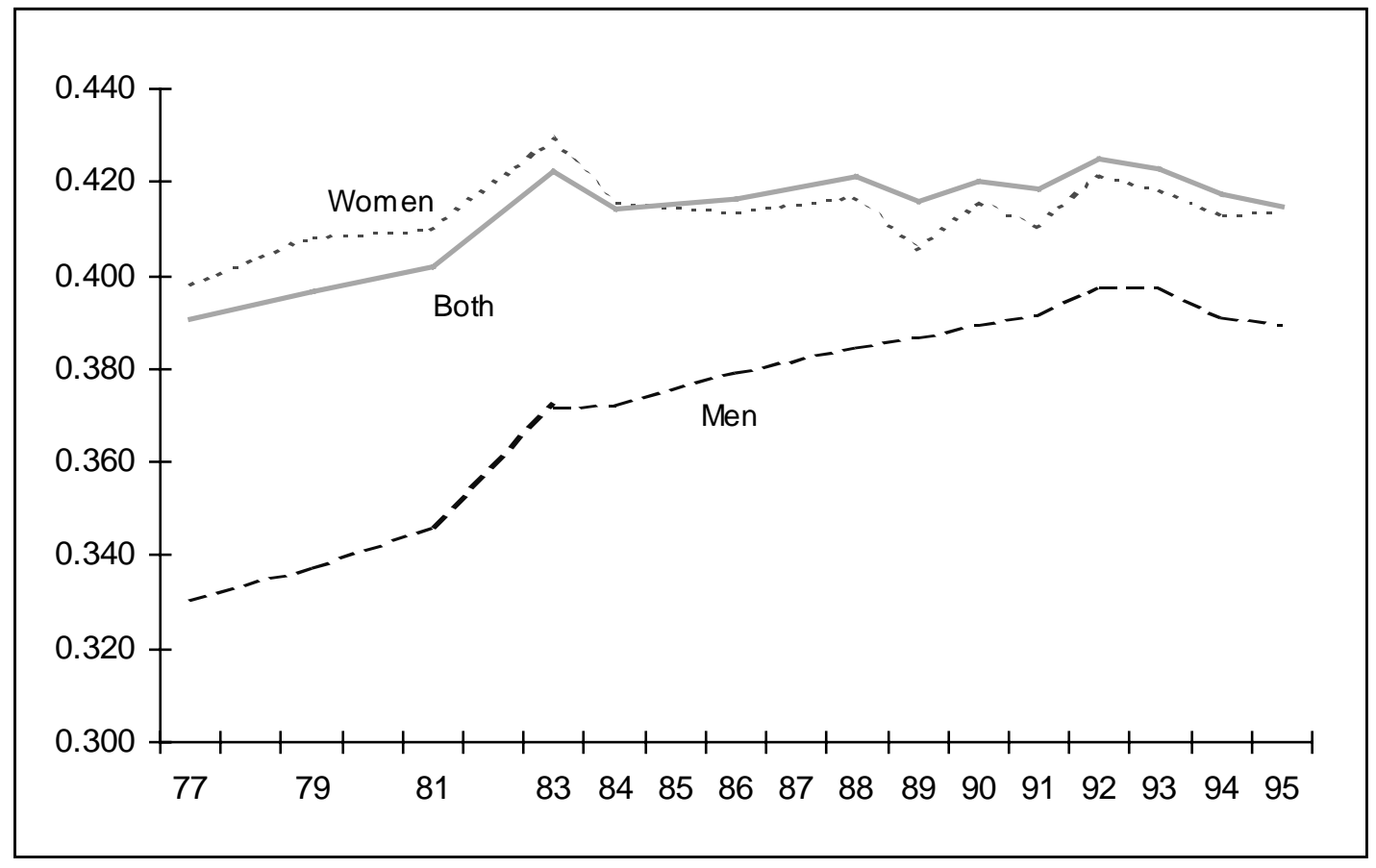


falls, earnings inequality is seen to rise. Polarization, on the other hand, is concerned with the share of workers that are at the bottom, middle or top of the earnings distribution. If the proportion of workers in the middle of the distribution falls (the declining middle), and the proportion at the top and/or bottom increases, polarization is seen to rise. Thus, roughly speaking earnings inequality deals with shifts in the share of earnings, while polarization measures are concerned with shifts in the share of workers among the distribution. Inequality asks whether the condition of workers at the bottom (or top) of the distribution has changed (with respect to earnings), while polarization asks whether the number of workers in various parts of the distribution has changed. The distinction between polarization and inequality measures are discussed in more detail in Wolfson, (1996b). Trends in earnings polarization do not necessarily reflect those of earnings inequality. For example, preliminary work by Wolfson and Murphy (1998) suggests that while earnings inequality continued to rise in the U.S. over the 1985 to 1995 period, earnings polarization fell.

Earnings polarization is measured here by dividing the earnings distribution into ten roughly equal categories, and then simply asking if the share of workers in these categories has changed through time. ${ }^{7}$ Increasing polarization would be associated with a rise in the share of workers at the bottom and top of the distribution, and fewer workers in the middle.

Among all employed workers there is no clear trend in polarization during any of the three periods that are deemed to be roughly in the same position of the business cycle (Chart 4). The chart shows the change in the share of workers between 1981-89, 1984-93 and 1986-95. During no period is there a clear trend towards a "declining middle" in the earnings distribution. This is for all paid workers, however. If one restricts the analysis to particular subsets of workers, clear trends in rising polarization are observed for the 1980s, but not the 1990s.

- Among full-time full-year workers, there are clear trends in rising polarization in the 1980s, as the share of workers in the bottom earnings category rose by 15 percentage points, in the top two by 10 to 20 points, with significant declines in the share in the middle (Chart 5). These kinds of patterns are not observed between the mid-1980s and mid-1990s, however. There is no clear polarization trend.

- Among employed men, there was a dramatic rise in polarization in the 1980s, but little evidence of a clear trend in the mid-1980s to 1990s. Between 1981 and 1989 the share of men in the two bottom earnings level rose by 20 percentage points, while the share in the top two levels rose 44 points. This was associated with a significant decline in the share of men in the middle of the earnings distribution (Table 2). During the 1986-95 period there is no clear patterns of rising or decreasing polarization among this group. If the analysis is restricted to men working full-time full-year in order to eliminate the effects of changing patterns of part-time/part-year work on earnings trends, increasing polarization is evident in both the 1980s, and to a lesser extent, between the mid-1980s and 1990s (data not shown).

7 This is done as follows. For the period of interest, workers are divided into deciles in the first (base) year, and the dollar value of the cut-points for the deciles determined. These dollar values are then inflated for other years using the change in the median earnings as the inflator. The share of workers in each of the ten categories (as defined by the inflated cut-points) for other years are determined. This is conceptually equivalent to calculating the share of workers in categories defined as some fixed percent of median income. Ten categories are used rather than the more commonly used three simply to provide a more detailed perspective of changes in the distribution of workers by earnings level. 
Chart 4: Change in the Proportion of Workers at the Bottom, Middle and Top of the Earnings Distribution, All Paid Employees

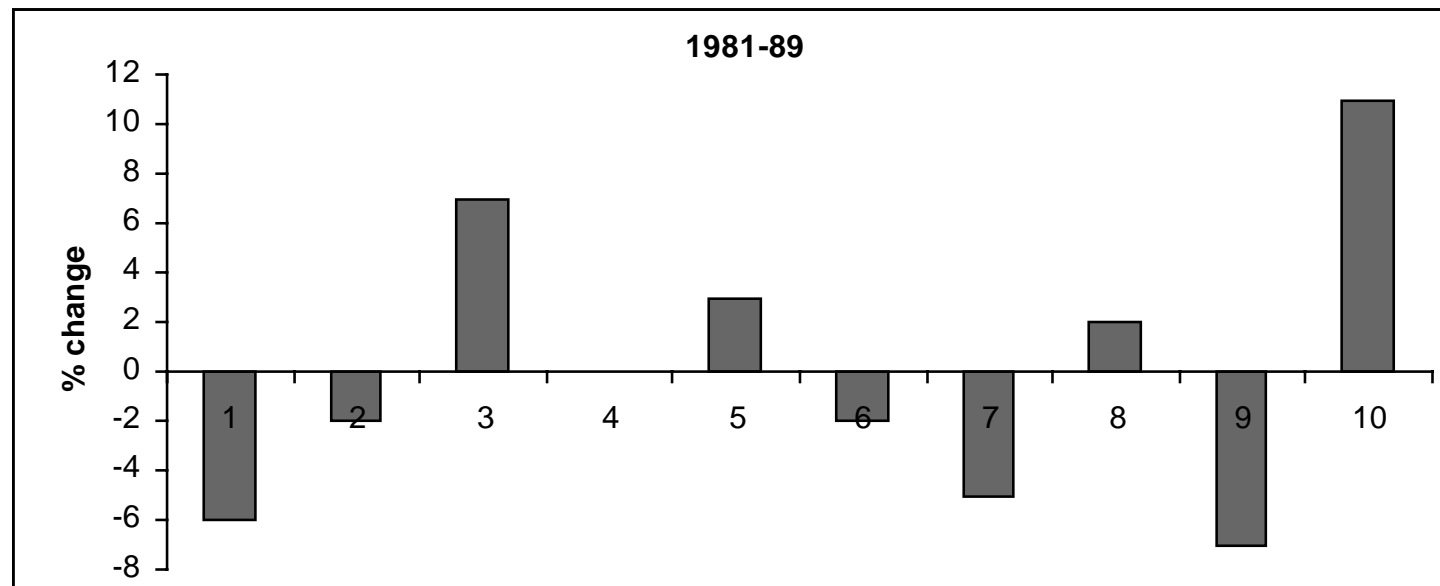

Earnings level
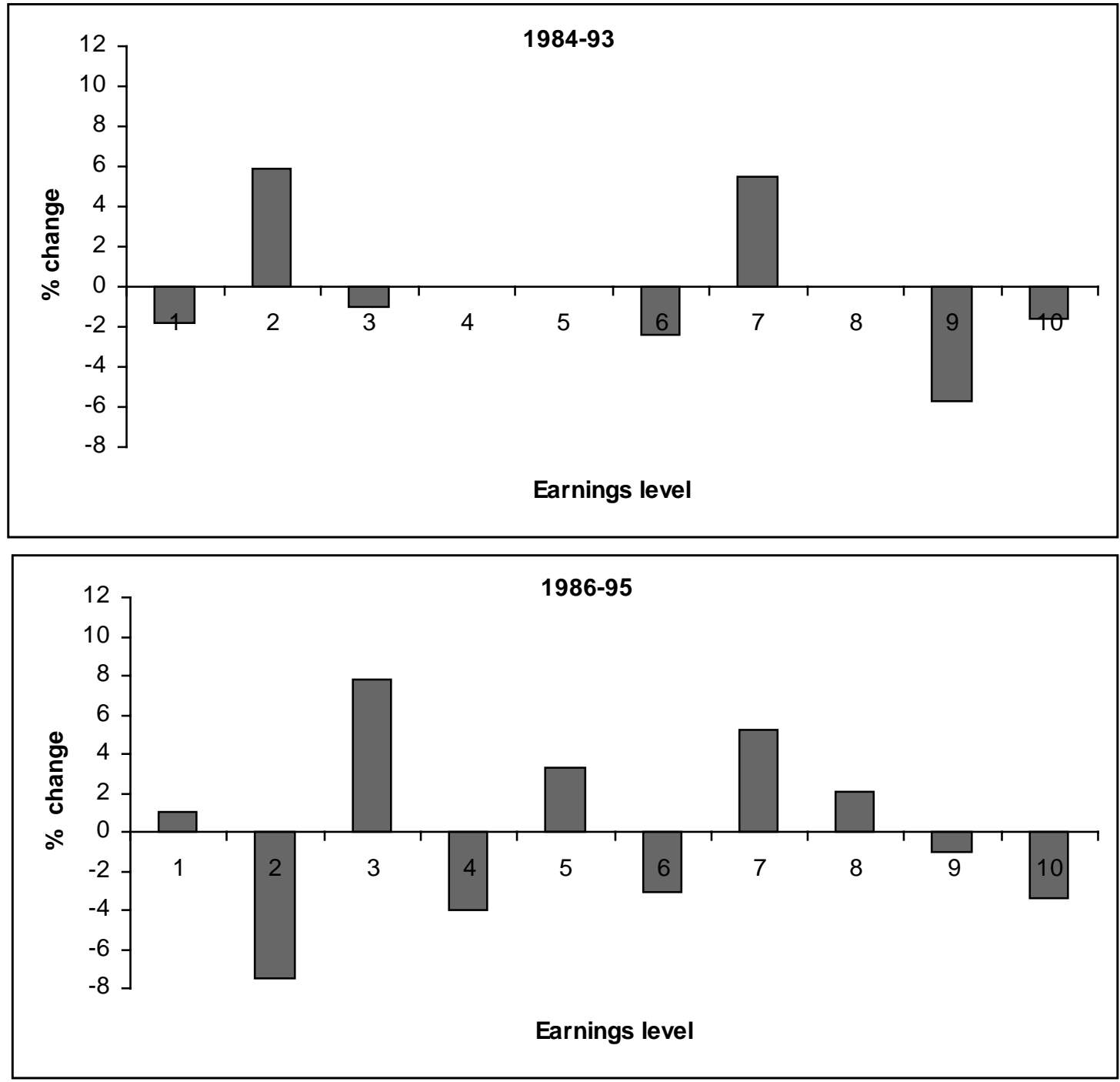
Chart 5: Change in the Proportion of Workers at the Bottom, Middle and Top of the Distribution, Full-Time Full-Year Paid Workers
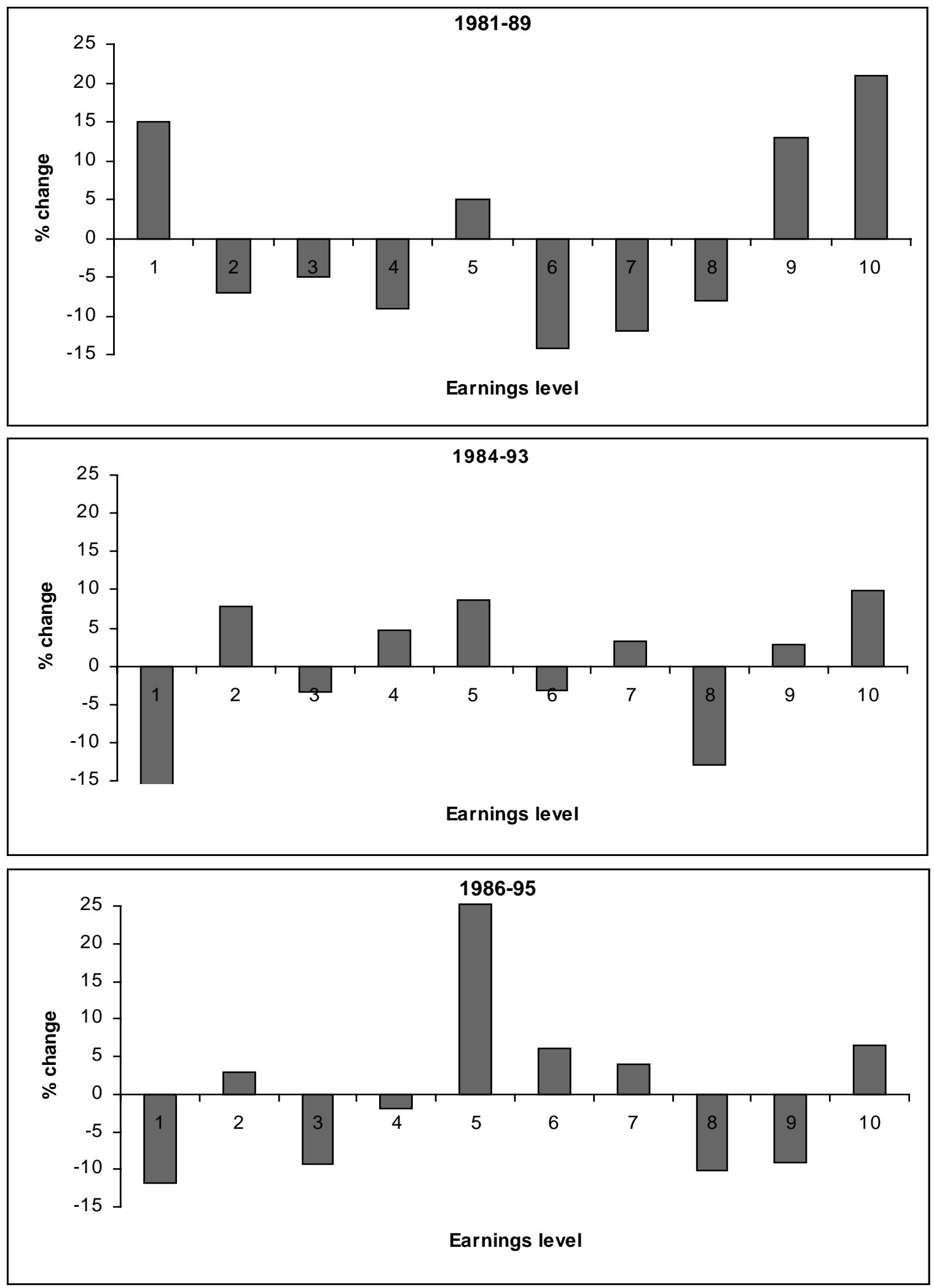
Table 2: Change in the Share of Paid Workers at the Bottom, Middle and Top of the Earnings Distribution, 1981-89, 1984-93, 1986-95

\begin{tabular}{|c|c|c|c|}
\hline \multicolumn{4}{|c|}{ Earning Levels in 1981 Dollars } \\
\hline Employed & 1981-89 & 1984-93 & 1986-95 \\
\hline \multicolumn{4}{|l|}{ Men and Women } \\
\hline$<\$ 2,200$ & -6.0 & -1.8 & 1.0 \\
\hline$\$ 2,200-\$ 4,618$ & -2.0 & 5.9 & -7.5 \\
\hline$\$ 4,619-\$ 7,637$ & 7.0 & -1.0 & 7.8 \\
\hline$\$ 7,638-\$ 10,606$ & 0.0 & 0.0 & -4.0 \\
\hline$\$ 10,607-\$ 13,515$ & 3.0 & 0.0 & 3.3 \\
\hline$\$ 13,516-\$ 16,420$ & -2.0 & -2.4 & -3.1 \\
\hline$\$ 16,421-\$ 19,814$ & -5.0 & 5.5 & 5.2 \\
\hline$\$ 19,815-\$ 23,755$ & 2.0 & 0.0 & 2.1 \\
\hline$\$ 23,756-\$ 29,500$ & -7.0 & -5.7 & -1.0 \\
\hline$>\$ 29,500$ & 11.0 & -1.6 & -3.4 \\
\hline \multicolumn{4}{|l|}{ Men } \\
\hline$<\$ 3,622$ & 10.0 & -0.7 & -4.8 \\
\hline$\$ 3,622-\$ 7,716$ & 10.0 & 1.9 & 7.7 \\
\hline$\$ 7,717-\$ 12,000$ & 5.1 & 1.9 & -0.9 \\
\hline$\$ 12,001-\$ 15,426$ & -10.8 & -1.3 & 1.2 \\
\hline$\$ 15,427-\$ 18,356$ & -15.0 & -9.6 & 0.0 \\
\hline$\$ 18,357-\$ 21,000$ & -15.3 & 10.1 & 0.0 \\
\hline$\$ 21,001-\$ 24,000$ & -17.3 & -12.8 & -16.1 \\
\hline$\$ 24,001-\$ 27,664$ & -10.7 & -10.1 & 2.3 \\
\hline$\$ 27,665-\$ 33,440$ & 14.0 & -10.3 & -10.3 \\
\hline$>\$ 33,440$ & 30.0 & 23.8 & 20.3 \\
\hline \multicolumn{4}{|l|}{ Women } \\
\hline$<\$ 1,500$ & -4.0 & 0.0 & 9.7 \\
\hline$\$ 1,501-\$ 3,000$ & -15.0 & 0.0 & 2.1 \\
\hline$\$ 3,001-\$ 4,842$ & 7.9 & 9.9 & -13.1 \\
\hline$\$ 4,843-\$ 7,000$ & 4.1 & -1.0 & 13.0 \\
\hline$\$ 7,001-\$ 9,265$ & 7.8 & -5.0 & -10.3 \\
\hline$\$ 9,266-\$ 11,500$ & 2.0 & -1.1 & 14.1 \\
\hline$\$ 11,501-\$ 13,620$ & 9.0 & 9.0 & 8.5 \\
\hline$\$ 13,621-\$ 16,172$ & -3.0 & -2.2 & -10.8 \\
\hline$\$ 16,173-\$ 20,568$ & -4.0 & -3.7 & 2.0 \\
\hline$>\$ 20,568$ & -4.0 & -2.4 & -9.8 \\
\hline
\end{tabular}

Table 3a: The Foster-Wolfson Polarization Measure

\begin{tabular}{|c|c|c|c|}
\hline Years & All Earners & Male Earners & Female Earners \\
\hline 1981 & .404 & .314 & .422 \\
1984 & .452 & .375 & .459 \\
1989 & .424 & .367 & .417 \\
1993 & .464 & .412 & .466 \\
\hline From Zyblock (1996a)
\end{tabular}

- Among all employed women the opposite was occurring in the 1980s, as the share at the bottom and top was declining, and the share in the middle was rising (Table 2). Polarization was decreasing, and offsetting the male trend in polarization to some extent. Recall that changes in polarization can be driven by changes in hours worked or wages. Earlier work (Morissette et al, 1994) suggests that much of the declining polarization was driven by women who work part- 
time working longer hours. If only full-time full-year women are considered, there is evidence of rising polarization during the 1980s.

An alternative approach is to use a polarization index developed by Foster and Wolfson ${ }^{8}$ (1993). It provides a single index number that measures polarization. Among all employed workers it shows some increase over the period, rising 5\% between 1981 and 1989, and 3\% between 1984 and 1993. It too suggests dramatic increases in polarization among men in the 1980 s, with a minor decline among women (Table 3a).

Different measures provide slightly different results. Overall, polarization may have increased marginally during the 1980s, but is not seen to increase significantly between the mid-1980s and mid-1990s. But as with the inequality measures, the polarization data suggest the labour market was a very different place for men and women. Men were dramatically polarized into increasing numbers at the bottom and top of the distribution in the 1980s, with some lingering effects in the 1990s. The opposite occurred among women in the 1980s, with little change since the mid-1980s.

To summarize, among all paid workers inequality and polarization is seen to rise only slowly during the 1980s and show little change from the mid-1980s to the mid-1990s. There has been a substantial increase in inequality and an associated decline in real earnings among men at the bottom of the earnings distribution, however. Inequality was seen to rise among female full-time full year workers as well during the 1980s, but not during the more recent past (mid-1980s to mid1990s). Among all female workers inequality changed little over the two periods, and if anything fell slightly during the 1980 s.

One can think about the earnings distribution as a large tent. If we restrict the tent to employed persons, we observe some small change in the overall shape of the tent over the past decade. What has been more significant is the movement within the tent as people exchange positions; some groups of workers have made gains, others have seen their relative position diminish. Generally speaking, relative annual earnings have tended to fall for the young, the lower paid/less skilled men, while increasing among older workers, the more highly paid/skilled men, and women. But what happens if we allow persons not employed into the tent. Do we then see a change in the overall shape over time, with inequality rising or falling?

\section{Inequality and Polarization Trends Among the Working Age Population}

Restricting measures of earnings inequality to paid workers presents a partial picture. Suppose overall employment opportunities or worker preferences for employment change such that there was a decline in the proportion of workers employed. Workers who were employed in an earlier period would have zero earnings in the present period, contributing to a possible rise in earnings inequality. However, they would be excluded from the calculation based only on paid workers. The effect of changes in the proportion of people working (either because of changes in workers preferences or the demand for labour) would be excluded. And the share of men employed has been

8 The Foster-Wolfson Polarization index is 0 if all population members have the same earnings, and 1 if there is a perfectly polarized population. See Wolson and Foster (1993) for a more detailed description. The index is $\mathrm{FWP}=2 *[2 *(0.5-\mathrm{SHARE} 50-\mathrm{GINI})] *$ (median/mean) where SHARE50 is the share of individual earnings in the bottom $50 \%$ of the distribution. 
falling, particularly in the 1990s. The male employment/population ratio fell from $72.8 \%$ in 1976 to $71.4 \%$ in 1989 , and then fell significantly to $65.4 \%$ by 1995 .

The opposite could occur if employment opportunities expanded, and a greater share of people were working. Groups of workers who tended to have zero earnings in an earlier period would now be employed, perhaps with low earnings. Based only on the population of earners, one might observe an increase in earnings inequality, as the number of persons with low earnings increased. If the entire population is included, earnings inequality would be seen to fall, as many workers went from zero earnings to low earnings. This has been the case among women, as the employment/population ratio went from $41.7 \%$ in 1975 to $53.7 \%$ by 1989 , and then levelled off, recording $52.1 \%$ in 1995 . Inequality could be seen to be falling much more when based on the working age population rather than employed workers.

Inequality measures computed for the entire working age population address a different question that was implicitly posed in the earlier section. When only paid workers are included it is changes in the earnings of persons holding jobs that is of concern. This section adds another dimension. Here, both the change in the propensity of people to hold jobs (the employment/population ratio) and earnings distributions (among those employed) are considered. Both influence the measures of earnings dispersion.

\section{Inequality Trends}

The inequality indexes suggest little change in earnings inequality among the population (aged 17 to 64) as a whole, and if anything a very minor decline (Chart 6, Table A-4). For example, the gini fell 3.2\% over the 1980s, was little changed between 1986 and 1995 (at .573 and .578), and in fact changed little between 1975 (at .585) and 1995 (.578). The cyclical variation in the gini is quite evident, and makes comparisons over time difficult. Using the method described in the earlier section, cyclical variation was removed. This resulted in a gini which is essentially flat for the entire working age population over the entire period covered, 1977 to 1995 (Chart 7). The alternative measures of inequality show the same results (Chart A-3).

This overall stability is the result of two offsetting trends. There was a significant decline in earnings inequality among women of working age. This was the result of more women entering employment, lower paid female workers in particular having more weeks of work per year, and rising average earnings of all women. The gini (with cyclical variation removed) fell by $9.9 \%$ between 1977 and 1990, and has remained flat since that time. The stabilization in the 1990s is likely related to the levelling on the female employment/population ratio. 
Chart 6: Gini Coefficient, Total Working Age Population, 1975-95

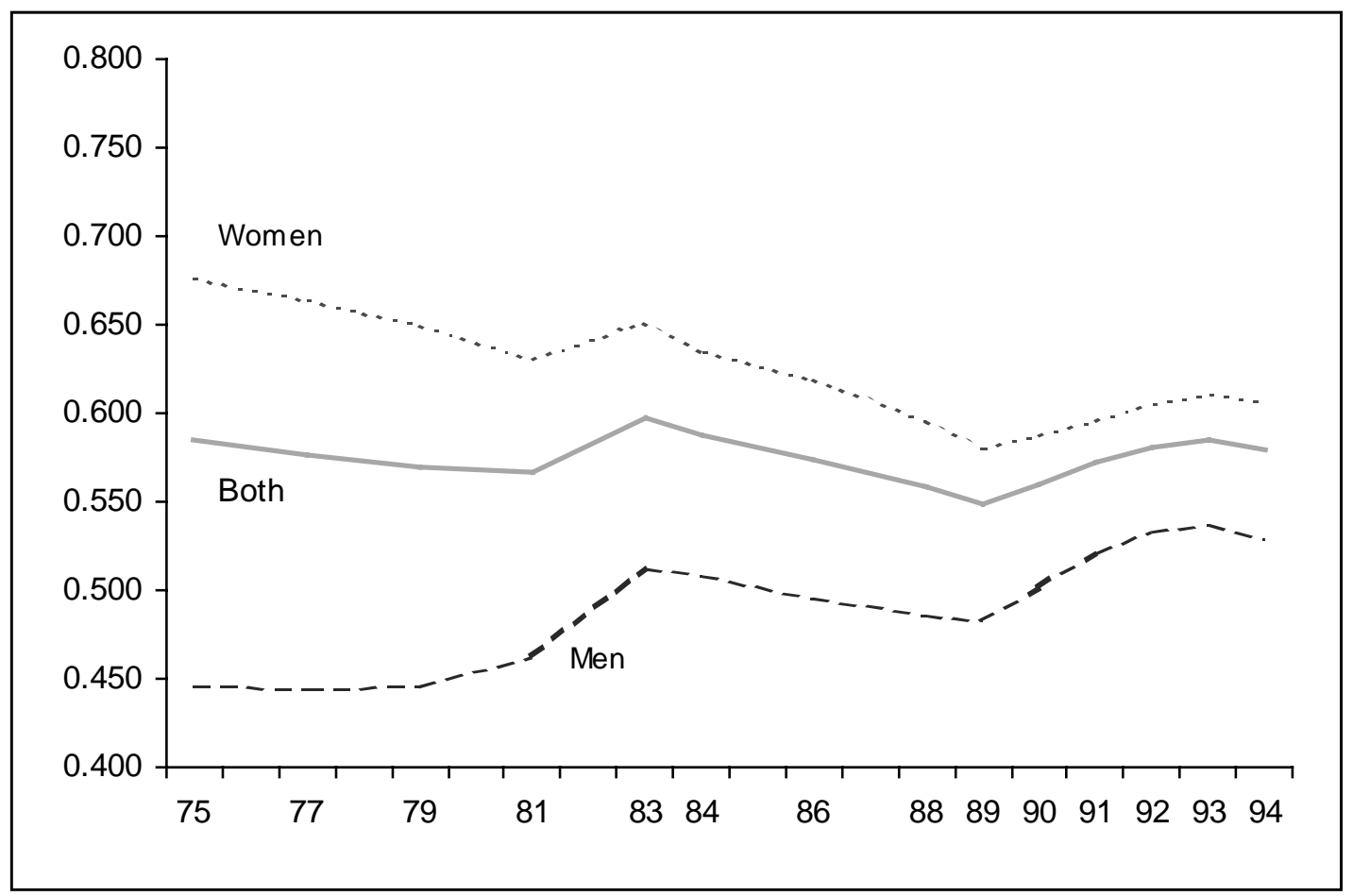

\section{Chart 7: Gini Coefficient with Cyclical Variation Removed, Working Age Population}

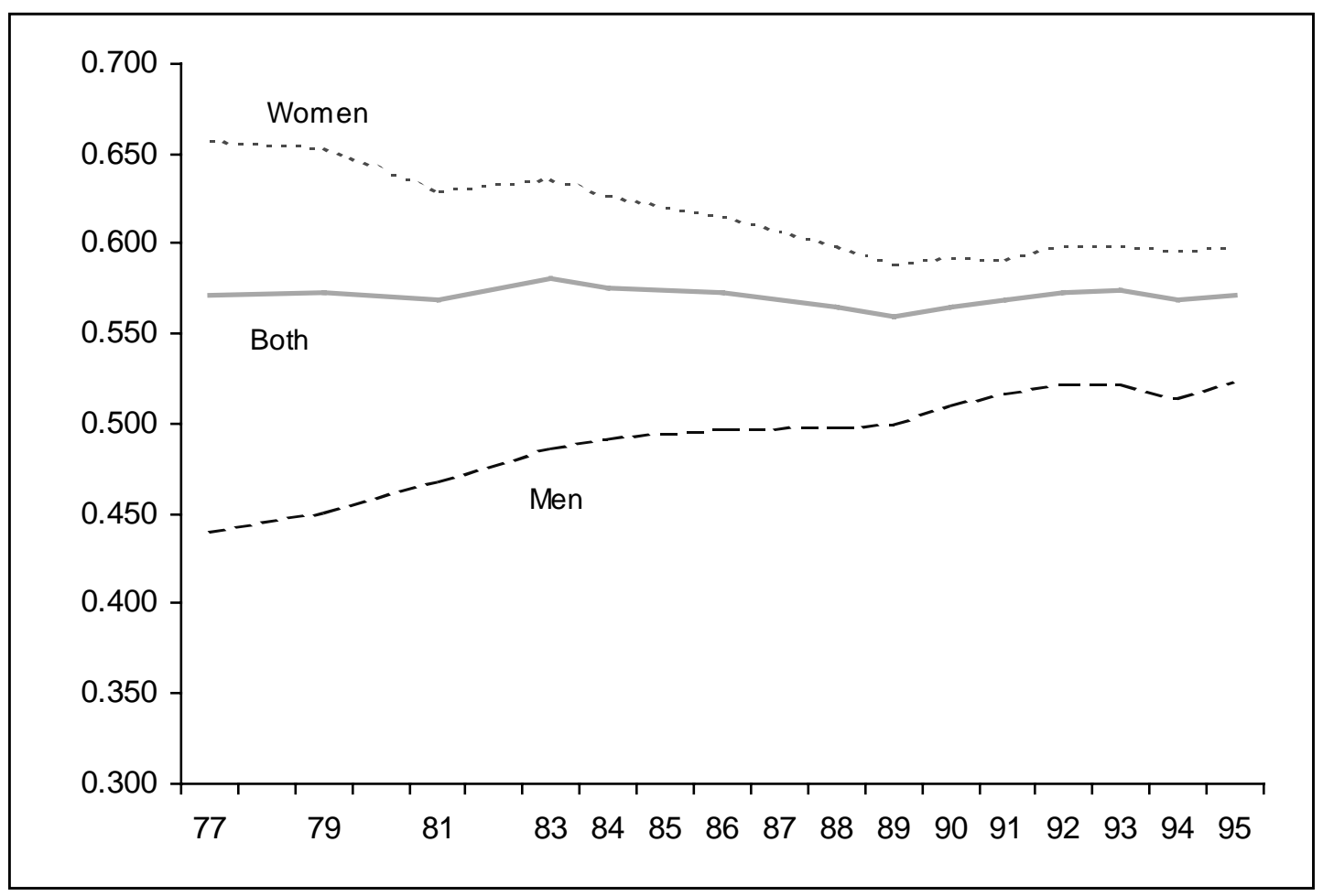


But there was also an increase in earnings inequality among working age men. It stemmed from lower paid males working fewer hours per week and weeks per year, average earnings falling among the lower paid, and the share with zero earnings rising, particularly in the 1990s. The gini rose more or less continuously between 1977 and 1995, increasing 18.9\%.

\section{Polarization Trends}

What do the polarization measures used earlier show? Among the working age population, the workers at the bottom of the earnings distribution have zero earnings. The share of workers with zero earnings has changed relatively little over the 1981 to 1995 period; it was $25.8 \%$ in 1981 , and $26.1 \%$ in 1995 (Table 3b). This is the result of offsetting trends; an increase in the share of men without earnings (related in part to declining employment/population ratios among older men), from $15.9 \%$ to $21.3 \%$ in 1995 , and a decline in the proportion of women without earnings, from $35.7 \%$ to $30.9 \%$. Thus, in the aggregate there has been relative stability in the share of people without earnings.

Since the mid-1980s there has been concern about the "declining middle", the notion that fewer people found themselves in the middle of the earning distribution, more at the extremes. For the working age population as a whole, the middle increased if anything, rather than declined, over the 1980s. Using the same approach as was described earlier (footnote 7), the share of workers in eight earnings categories is determined. Chart 8 shows that during the 1980s the share in the middle of the distribution $\left(3^{\text {rd }}\right.$ and $4^{\text {th }}$ groups) rose around 20 percentage points during the $1980 \mathrm{~s}$, while the share at the top and bottom of the distribution fell. A similar trend is observed for the 1984-93 period, but by 1986-95 there is no observable trend in polarization whatsoever. These data suggest decreasing polarization among the working age population as a whole during the 1980s, and little change in the 1990s.

As has often been the case, this is again a story of offsetting trends between men and women. Over all three periods, there has been increasing polarization among men in the working age population, and decreasing polarization among women. The share of men at both the bottom and top of the distribution rose in all periods, while the share in the middle declined. There has been an "declining middle" among men of working age. Among women the opposite is true. The share at the bottom and top of the distribution has declined, while the share in the middle has increased. There has been an "increasing middle" among women of working age (Table 4).

Table 3b: Proportion of the Working Age Population Aged 17-64 with Zero Earnings

\begin{tabular}{|c|c|c|c|}
\hline Year & Men and Women & Men & Women \\
\hline 1981 & $25.8 \%$ & $15.9 \%$ & $35.7 \%$ \\
1984 & $26.8 \%$ & $18.2 \%$ & $35.4 \%$ \\
1989 & $22.2 \%$ & $16.2 \%$ & $28.0 \%$ \\
1993 & $26.0 \%$ & $21.0 \%$ & $30.9 \%$ \\
1995 & $26.1 \%$ & $21.3 \%$ & $30.9 \%$ \\
\hline
\end{tabular}


Table 4: Change in the Share of the Working Age Population at the Bottom, Middle and Top of the Earnings Distribution, 1981-89, 1984-93, 1986-95

\begin{tabular}{|c|c|c|c|}
\hline \multicolumn{4}{|c|}{ Earning Levels in 1981 Dollars } \\
\hline & 1981-89 & $1984-93$ & 1986-95 \\
\hline \multicolumn{4}{|l|}{ Men and Women } \\
\hline$<\$ 1,092$ & -11.0 & -3.5 & 3.8 \\
\hline$\$ 1,093-\$ 4,035$ & 10.0 & 5.3 & -11.4 \\
\hline$\$ 4,036-\$ 8,008$ & 24.0 & 6.5 & -1.0 \\
\hline$\$ 8,009-\$ 12,091$ & 22.0 & -1.2 & 4.3 \\
\hline$\$ 12,092-\$ 16,000$ & 9.2 & 2.6 & 9.6 \\
\hline$\$ 16,001-\$ 20,644$ & -2.0 & 8.1 & -5.2 \\
\hline$\$ 20,645-\$ 27,000$ & -4.0 & 3.1 & 1.0 \\
\hline$>\$ 27,000$ & -24.8 & -7.1 & -3.2 \\
\hline \multicolumn{4}{|l|}{ Men } \\
\hline$<\$ 1,664$ & 2.5 & 8.5 & 17.9 \\
\hline$\$ 1,665-\$ 5,893$ & -2.0 & -4.9 & -20.0 \\
\hline$\$ 5,894-\$ 10,800$ & 8.0 & -10.3 & -13.7 \\
\hline$\$ 10,801-\$ 15,184$ & -11.0 & -10.1 & -6.1 \\
\hline$\$ 15,185-\$ 18,778$ & -16.0 & -11.9 & -18.2 \\
\hline$\$ 18,779-\$ 22,004$ & -21.0 & -11.9 & -29.4 \\
\hline$\$ 22,005-\$ 26,012$ & -9.0 & -13.1 & -19.1 \\
\hline$\$ 26,013-\$ 32,233$ & 13.0 & -10.0 & -5.4 \\
\hline$>\$ 32,233$ & 32.0 & 20.4 & 37.7 \\
\hline \multicolumn{4}{|l|}{ Women } \\
\hline$<\$ 800$ & -12.3 & -9.0 & -2.9 \\
\hline$\$ 801-\$ 3,000$ & 51.5 & 36.4 & 8.3 \\
\hline$\$ 3,001-\$ 6,022$ & 62.7 & 32.0 & 12.5 \\
\hline$\$ 6,023-\$ 9,648$ & 84.0 & 32.4 & 20.3 \\
\hline$\$ 9,649-\$ 13,086$ & -17.0 & 11.6 & -3.8 \\
\hline$\$ 13,087-\$ 17,732$ & -51.0 & -21.6 & -13.8 \\
\hline$>\$ 17,732$ & -82.0 & -51.4 & -39.7 \\
\hline
\end{tabular}


Chart 8: Change in the Share of the Working Age Population at the Bottom, Middle and Top of the Earnings Distribution
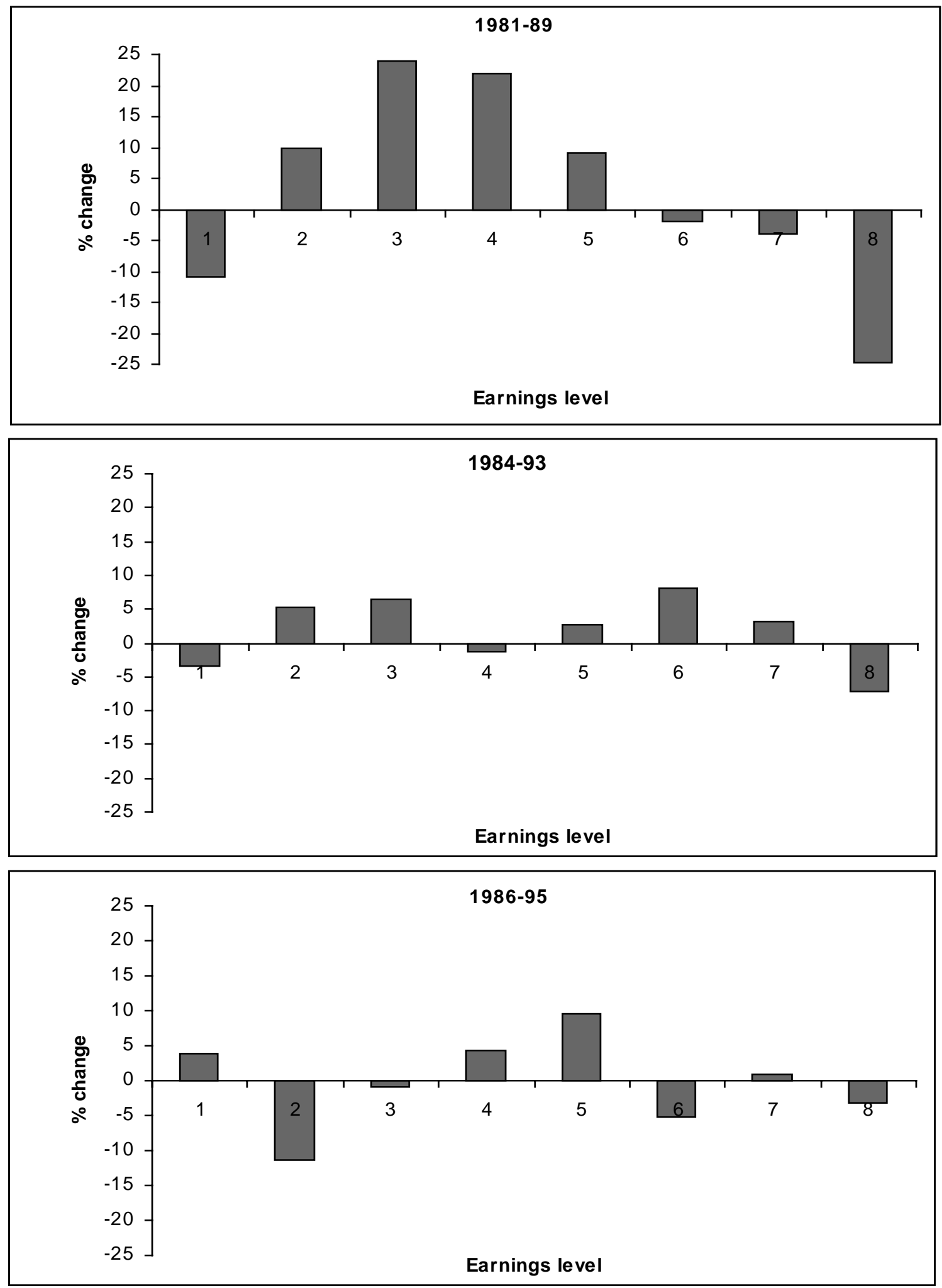
To summarize, when one takes a very broad perspective on the manner in which the labour market is distributing earnings, the story of rising polarization and inequality largely disappears for the period since the mid-1980s. And when the combined effects of both changes in the employment/population ratio and earnings trends among job-holders are included, inequality is not seen to have risen during the 1980s or 1990s. But this is not a reason for complacency regarding earnings trends in the labour market. This aggregate result is simply the culmination of numerous offsetting trends, some of which have resulted in deteriorating conditions for many workers. One such trend has been the decline in real and relative earnings of the young.

\section{The Rising Earnings Differential Between the Young and the Old: Is it Wages or Hours Based?}

One dimension of the inequality story has been the increasing gap in annual earnings between younger and older workers, particularly among men. This has been largely due to declines in real earnings among young workers, and has been well documented in Canada (Myles, Picot and Wannell (1988), Betcherman and Morissette (1994), Morissette, Myles and Picot (1994), Beaudry and Green (1996), and for other industrialized countries (Davis, 1992). The goal here is to determine the extent to which falling earnings are associated with changes in hourly wages on one hand, or hours worked (either changes in weeks per year or hours per week) on the other. Earlier work has suggested that changes in hours worked (either weeks per year or hours per week) have played a significant role in changing inequality among men and women (Morissette, Myles and Picot, 1994; Morissette, 1995). The goal here is to update the trends in earnings of the young and old, and ask whether the changing relative hours play a similarly significant role in the changes in relative annual earnings between younger and older workers.

We focus on all workers, including part-time and full-time. This is necessary if one is to capture all the changes taking place in patterns of working time. Restricting the analysis to full-time full-year workers would limit the potential change in the weeks worked per year and hours per week variables.

\section{Changing Annual Earnings Among Young Males}

Much of the decline in real average annual earnings among young males (aged 18 to 24) occurred during the early 1980s (Chart 9). Of the 36\% drop in earnings between 1979 and the early 1990s, over $60 \%$ of it occurred between 1979 and 1983. There was little recovery during the late 1980s, and a subsequent smaller decline during the recession of the 1990s. Among 25-34 year olds, whose earnings have fallen about $14 \%$ since 1979 , most of the decline was in the 1980s recession, again with no recovery through the 1980s. There have been significant changes in the number of young people working part-time over this period, but this is not entirely responsible for these trends, as the same general pattern is observed for full-time full-year workers (Chart 9).

To assess the role of hours worked and hourly wages in these trends, we simply examine the relative values of four variables: annual earnings, annual weeks worked, hours per week, and hourly wage rate. To do so requires data not available in the Survey of Consumer Finances (the data source used in all parts of the paper to this point). In particular it is difficult to obtain reliable data on the hourly wage rate from the SCF. Hence, data from three special surveys are used, the Survey of Work History (SWH) of 1981, the Labour Market Activity Survey (LMAS) of 1986 to 1990 inclusive, and the Survey of Labour and Income Dynamics (SLID) of 1993. All of these surveys 
collect data on hourly wages, annual weeks worked, hours per week. Annual earnings can be derived from these variables.

The ratios computed are the average value of the variable for younger workers (under 35) relative to those for older workers (over 35). The change in these relative values over time will inform us as to which variables are associated with the decline in relative annual earnings among young male workers.

For men, the ratio of average annual earnings of workers under 35 to those over 35 fell from .64 in 1981 to .57 in 1989, and .55 in 1993 (Chart 10). Was this decline associated with a fall in relative weeks worked, hours per week, or hourly wages? The answer appears to be hourly wages. Relative weeks worked changed little over the period (at around .87), as did relative hours worked per week (at .95). Relative hourly wages, however, fell from .84 in 1981 to .71 in 1989, and to .67 in 1993 . This would suggest that virtually all of the decline in relative annual earnings among the young between 1981 and 1989 was associated with falling relative hourly wages ${ }^{9}$.

\section{Changing Annual Earnings Among Young Women}

As with the men, the real annual earnings of young women fell between 1977 and 1983 (about $21 \%$ ), recovered somewhat during the 1980s, and fell again in the 1990s recession and beyond. The fall between the late 1970s and the mid-1990s was 29\%. This was for all female workers. Among women working full-time full-year, the story was one of a decline in the early 1980s, followed by recovery in the late 1980s and early 1990s, so that overall there was little change over the entire period. (Chart 11). Average earnings among older women (over 24) rose in all age categories, but more so among the older than younger workers, so that the relative annual earnings of 25-34 year olds fell from 0.8 in 1981 to 0.7 in 1993 . The relative decline was greater among full-time full-year workers.

Were these declines in the relative earnings associated with declining relative wages or working time? The answer is both. Relative hourly wages have fallen among women under 35 (relative to those over 35), from 0.9 in 1981 to 0.8 in 1993. But relative hours worked per week have fallen as well, from 1 to 0.9 . Thus, both have contributed to the decline in relative annual earnings. ${ }^{10}$

Overall, the decline in annual earnings of the young appear to have more to do with changes in relative wages than in working time.

9 To ensure that this result is not specific to this particular way of grouping younger and older workers, this same approach was used for other combinations of workers, and results compared for two periods, 1981-89 and 198493. Two separate younger age groups, 17-24 and 25-35, were compared with the central age group of older workers, those 45 to 54 . Generally speaking, changing relative wages dominated the other variables. The one exception was among the 17-24 years olds during the 1984-93 period, where relative hours worked per week (relative to $45-54$ year olds) decline $12 \%$ compared to a decline in hourly wages of $18 \%$. Overall, however, the decline in relative (and real) annual earnings among the young appears to be associated with changing relative hourly wages, not changing relative hours worked per year.

10 As with men, this was tested using narrower age groups (17-24 and 25-34) for women, and determining change relative to the 45 to 54 aged population. The results were similar to those for the broader age groups. 
Chart 9: Indexed Real Annual Earnings of Paid Male Workers, by Age Group, 1969-95 (1969=100)
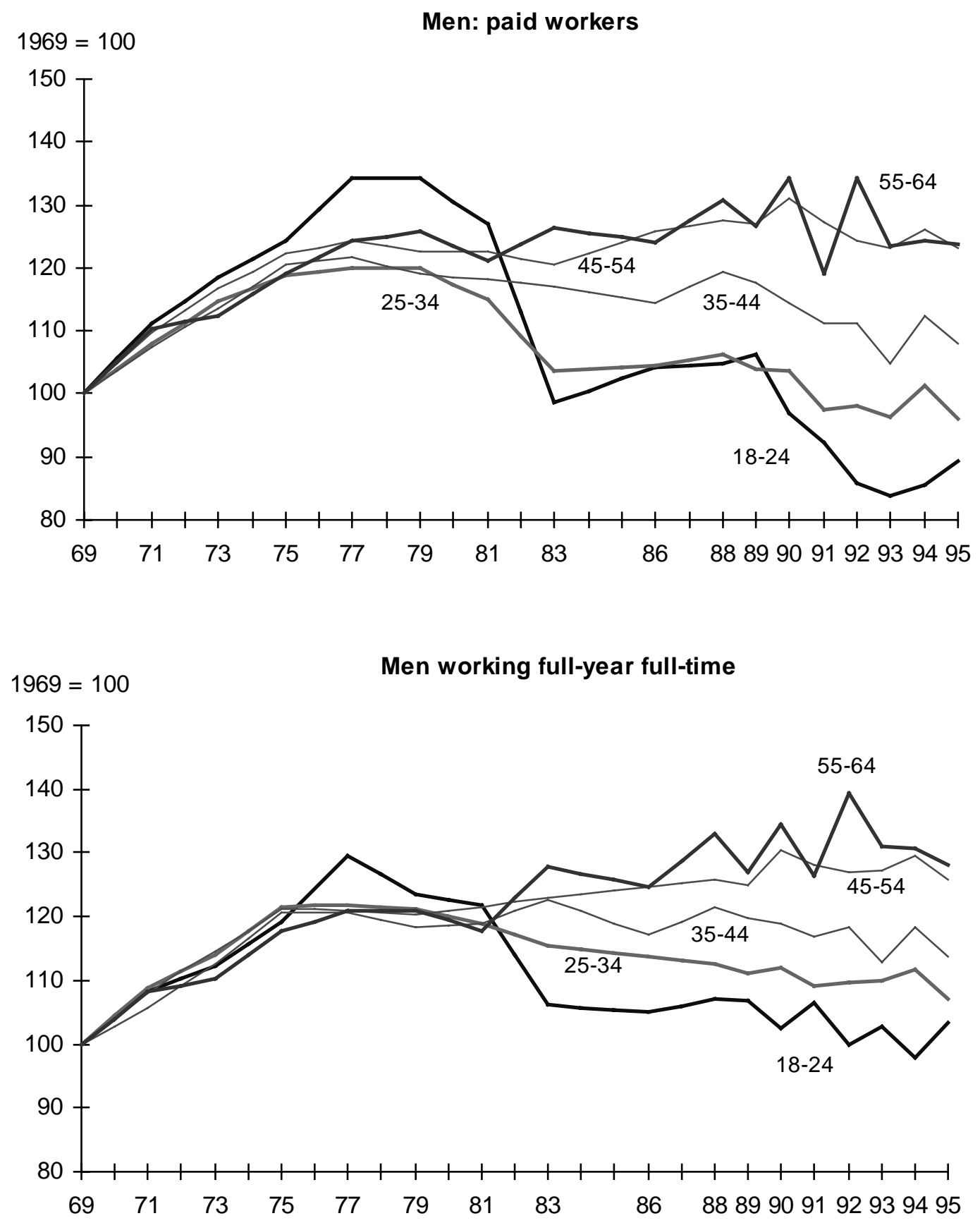
Chart 10: Relative Measures of Earnings and Hours: Workers under 35 relative to those over 35
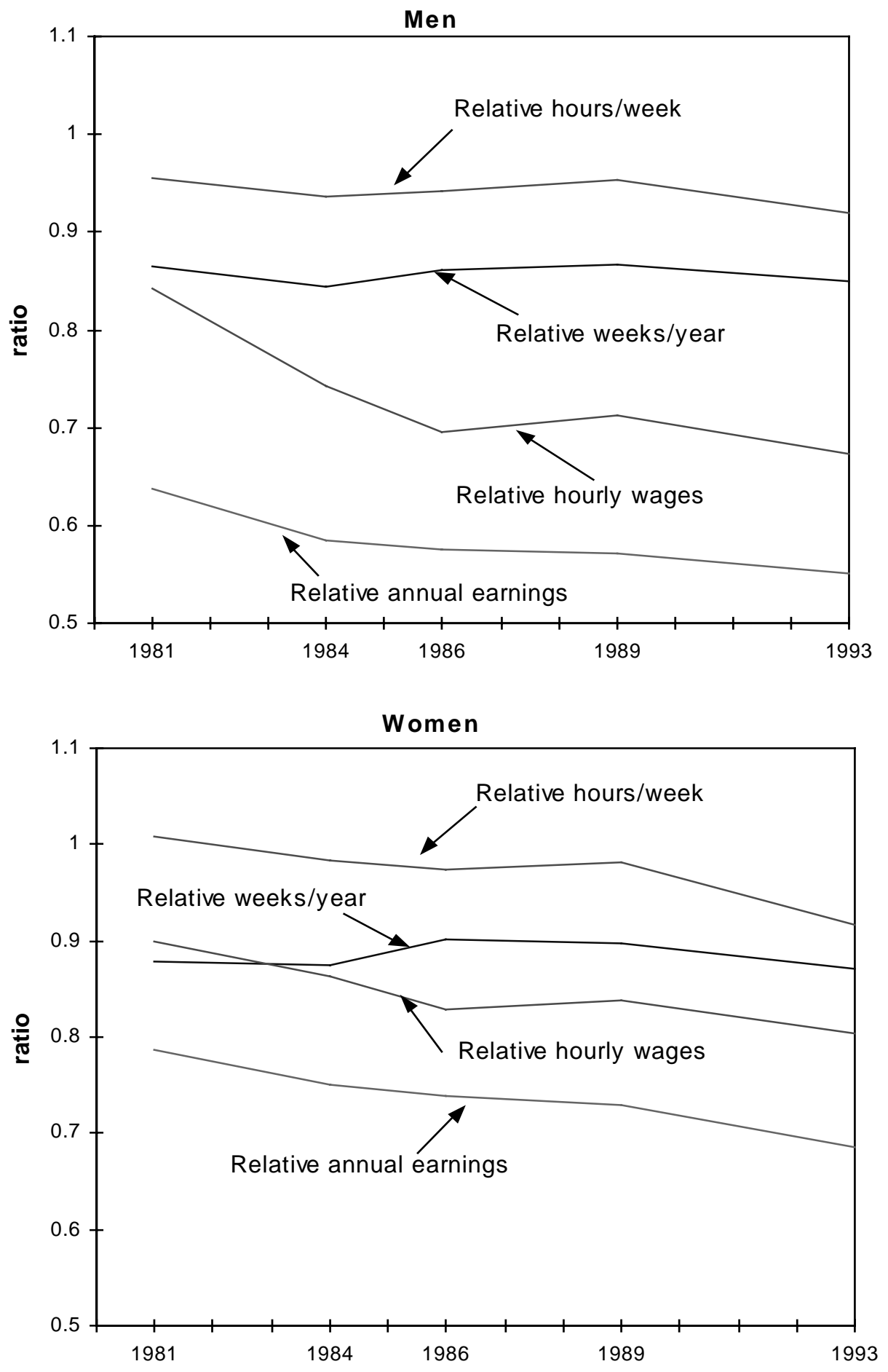


\section{Chart 11: Indexed Real Annual Earnings of Female Paid Employees, by Age Groups,}

1969-1995 (1969=100)
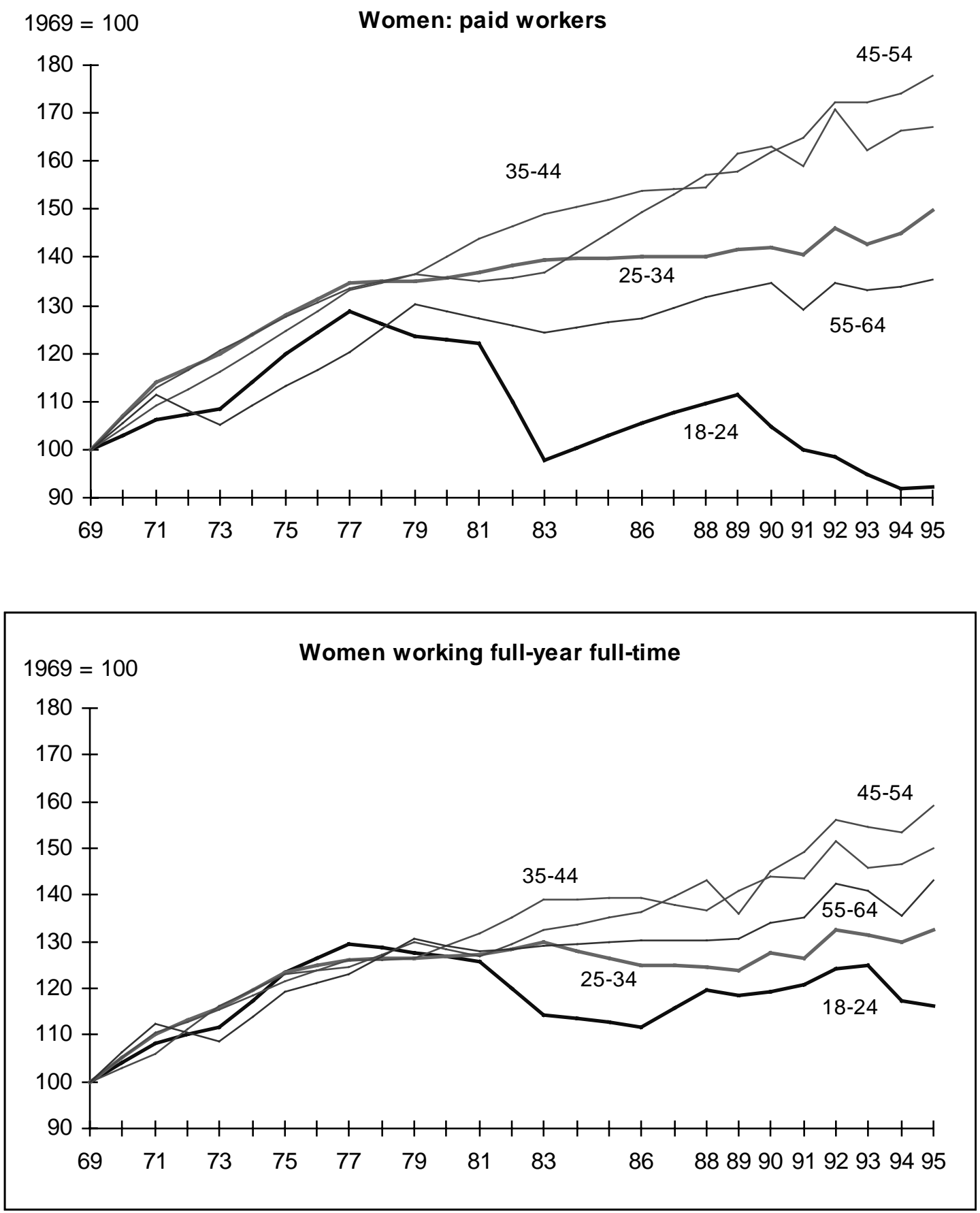


\section{Conclusion}

Real and relative hourly wage rates have declined among younger workers. The reasons are not well known. Some argue that in a world of rapid technological change, older workers are receiving an increasing wage premium on experience (Davis, 1992). There may be other reasons. Adjustment of almost any type is typically more concentrated among younger workers. This includes migration, adjusting to changing regional economic circumstances, changes in skill acquisition in the face of changing labour demand, and wage adjustment.

It is likely easier for companies to adjust the wages of entry (or near entry) level jobs downward in the face of decreased labour demand than it is to adjust the wages in jobs filled by experienced workers for reasons given above. This would influence the wages of predominantly younger workers, particularly during the recessionary years of the 1980s and 1990s, when most of the decline in youth earnings was observed. Many older workers may be relatively immune to the substantial downward adjustment of wages, as employers may be concerned about the effect on morale and productivity. The downward stickiness of wages has been noted for some time.

In addition, the educational levels of older workers have been increasing relative to the younger. The baby-boom generation experienced a tremendous increase in educational attainment compared to earlier cohorts. As this generation ages, the educational attainment of older workers rises relative to the young, and hence the relative wages of the young would be seen to fall. The educational advantage that younger workers once had over their older counterparts has largely disappeared in the 1990s. It is estimated that this change in relative educational level may account for $25 \%$ to $30 \%$ of the increasing wage gap between younger and older workers (Kapsalis, Morissette and Picot, 1997).

The concern regarding the declining youth wage rates is intensified because longitudinal analysis conducted suggests that these younger cohorts do not "catch -up" to the earlier cohorts as they age and acquire more experience. Work by Beaudry and Green (1996) and Morissette and Bérubé (1996) suggest that the cohort-specific age earnings profile of men has shifted downwards for successive cohorts of young men through the 1980s. Furthermore, the work by Beaudry and Green suggests that this occurs across all educational levels. Having a university degree did not protect younger male workers from this downward shift in the age-earnings profile.

The rising wage gap between the young and old is one of a number of disconcerting trends in earnings. In the aggregate, however, earnings inequality/polarization has changed little over the past decade. It increased only slowly if at all among all paid workers, and declined marginally among the working age population. When the effect of changing employment/population ratios is included, earnings inequality is seen to change relatively little, and if anything declined over the past fifteen years among the working age population. This relative stability is the result of a number of offsetting trends. Understanding these trends is important if yet we are not to be deceived by the stability in the aggregate, and possibly become complacent regarding labour market earnings trends. Inequality increased significantly among male workers, all full-time full-year workers, and the entire male working age population. However, it fell among female workers, and in particular among the female working age population, as the proportion of women working rose through the 1980s. 
Translated into the effect on real annual earnings, those of men in most parts of the earnings distribution fell over the 1980s and early 1990s (except for those at the top). This decline was particularly concentrated among the lower paid and presumably less skilled males. Earlier work suggests that changes in hours and weeks worked played a major role in these changes in annual earnings. The opposite trend occurred among women. Annual earnings of women in all parts of the distribution rose. The significant gap in earnings levels between men and women persists, however.

It is important to note the relative stability in earnings inequality, which is at odds with the prevalent perception that labour market inequality continues to increase. It is also important to realize that there have been significant changes in the earnings patterns for many groups. The overall relative stability in earnings inequality masks a substantial redistribution of working time, wage rates and earnings among Canadian workers. Some groups are gaining, notably older workers, women in general, and the more highly paid and skilled, while others experienced declines, notably low skilled young males, the young in general, and lower paid/lower skilled men.

It is difficult to speculate as to whether this relative stability in inequality will persist through the 1990s and beyond. That is because the underlying causes of the original increase are not well understood. Many factors have been observed to contribute, but no definitive cause has been identified (Morissette, 1995). If skill-biased technological change is indeed the predominant cause (Bound and Johnston, 1992), then there is no reason to believe that this influence will abate over the coming period. Nor is there any reason to believe that it slowed during the past decade either, although the growth rate in inequality slowed.

As noted, aggregate inequality trends are the culmination of a number of offsetting trends among different populations. It may well be that the causes for the variation in earnings among these different groups are themselves different. What is resulting in the declining (real and relative) earnings among lower paid/lower skilled males (quite possibly technological change) may be very different than what is behind the rising relative earnings of older workers, or the declining earnings of young males, or the rising real and relative earnings among women. Perhaps the search for causes should focus on changes in earnings patterns among particular groups, rather than focusing on aggregate inequality. This is quite often done. Earnings patterns among males are the topic of much research for this reason. Unfortunately, this focus also inadvertently contributes to the notion that significant increases in inequality continue. The purpose of this paper was to provide a broader perspective. There is one point worth noting. The downturn in earnings in the bottom deciles in 1995, an expansionary year where these earnings should have been increasing for these groups, gives one pause. Whether this will be reversed remains to be seen.

Finally, we have focused on the distribution of employment earnings to individuals. This places the focus on the functioning of the labour market. From a welfare perspective one might be more interested in market earnings on a family basis, since it is family income that determines well-being for most Canadians. Inequality in family market income (mainly employment earnings) has increased in Canada during the recent past (Zyblock, 1996b), in spite of the relative stability in individual earnings inequality. Family (total) income inequality has not risen (Beach and Slotsve, 1996), however, in large part due to the transfer system. 


\section{Appendix}


Appendix Chart A-1: Index of Real Annual Earnings by Selected Decile, Men and Women Combined, 1981-1995

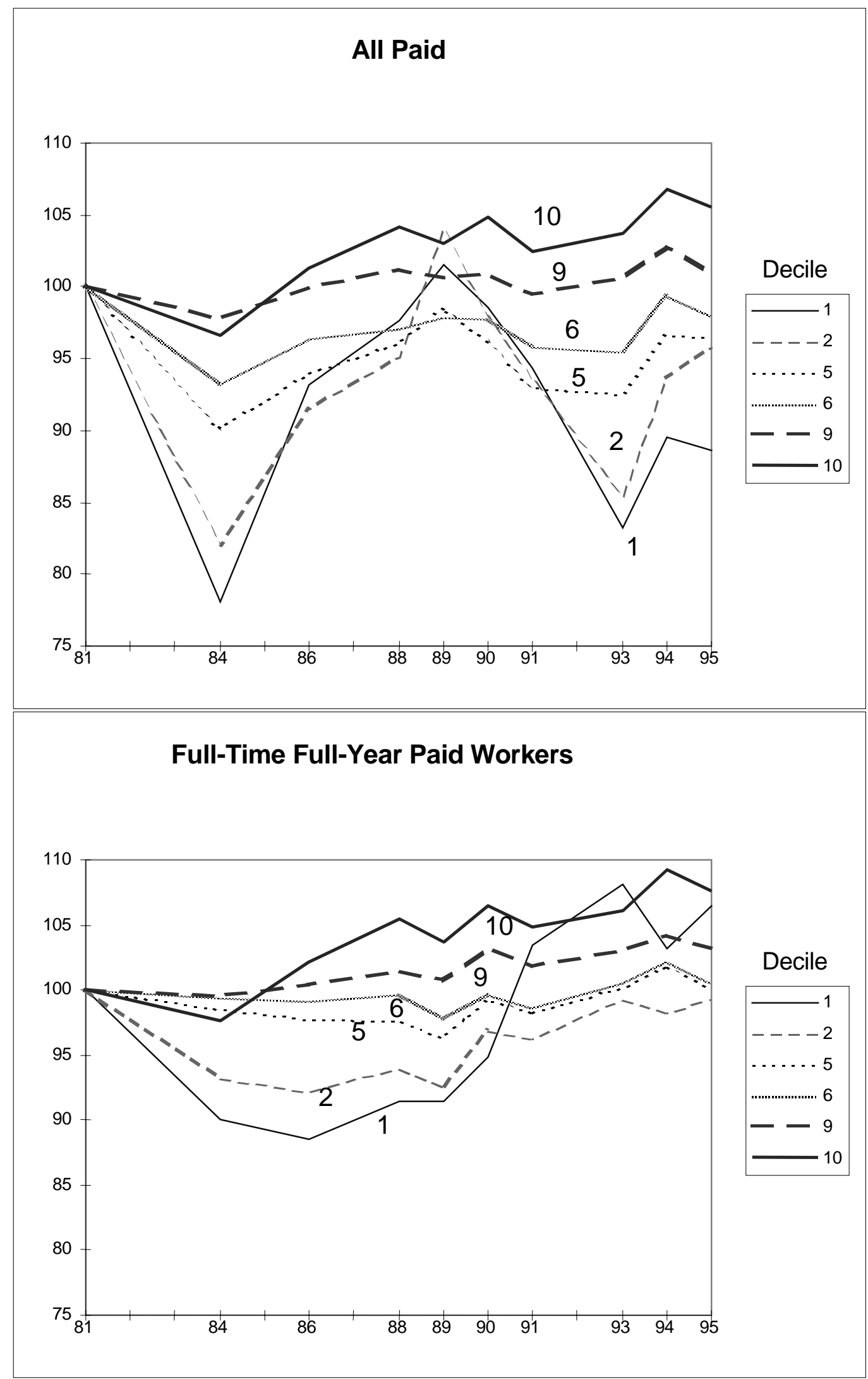


Appendix Chart A-2: Exponential and CV Measures of Inequality, Paid Employees, 1975-94
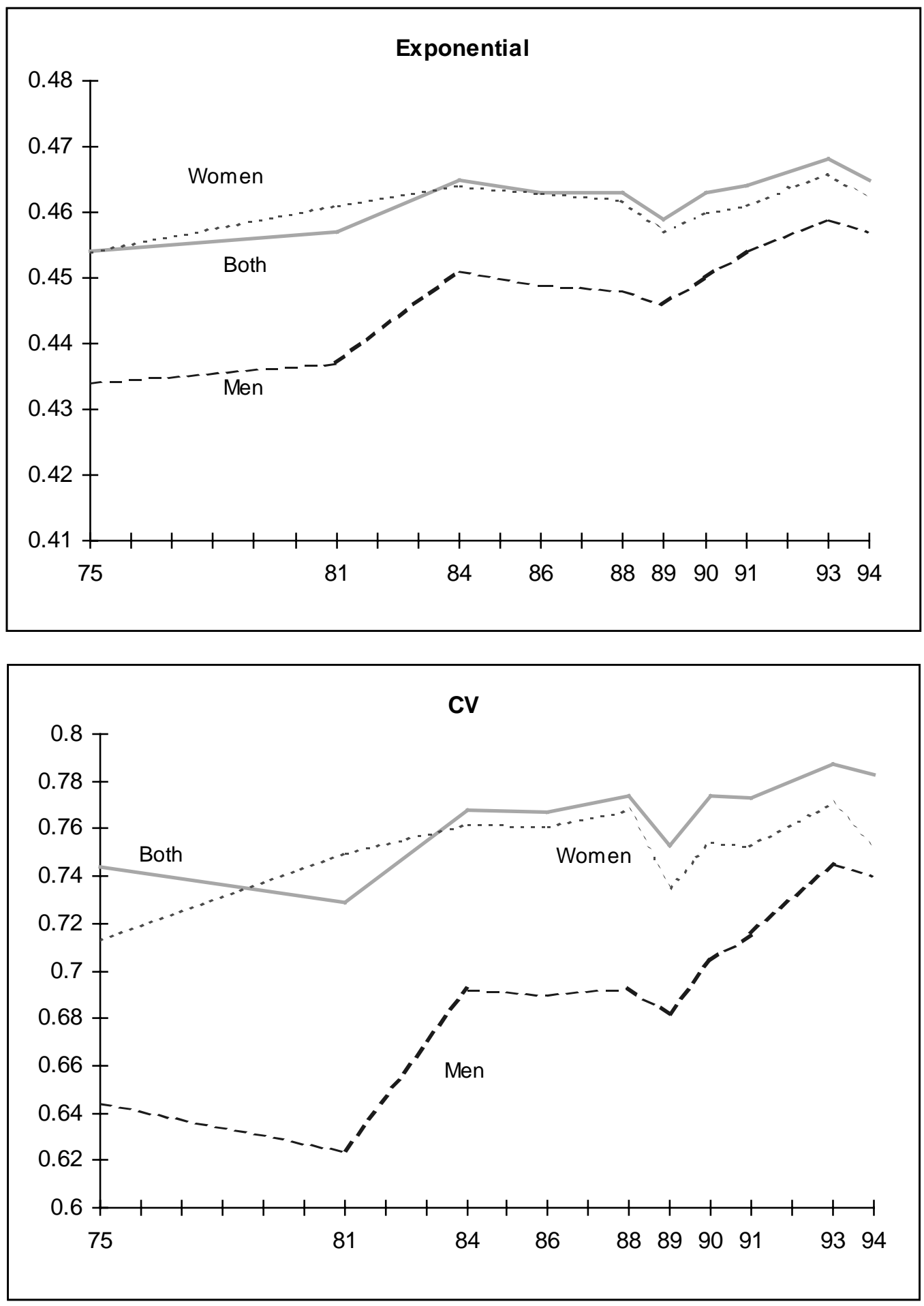
Appendix Chart A-3: Exponential and CV Measures of Inequality, Total Working Age Population, 1975-1994
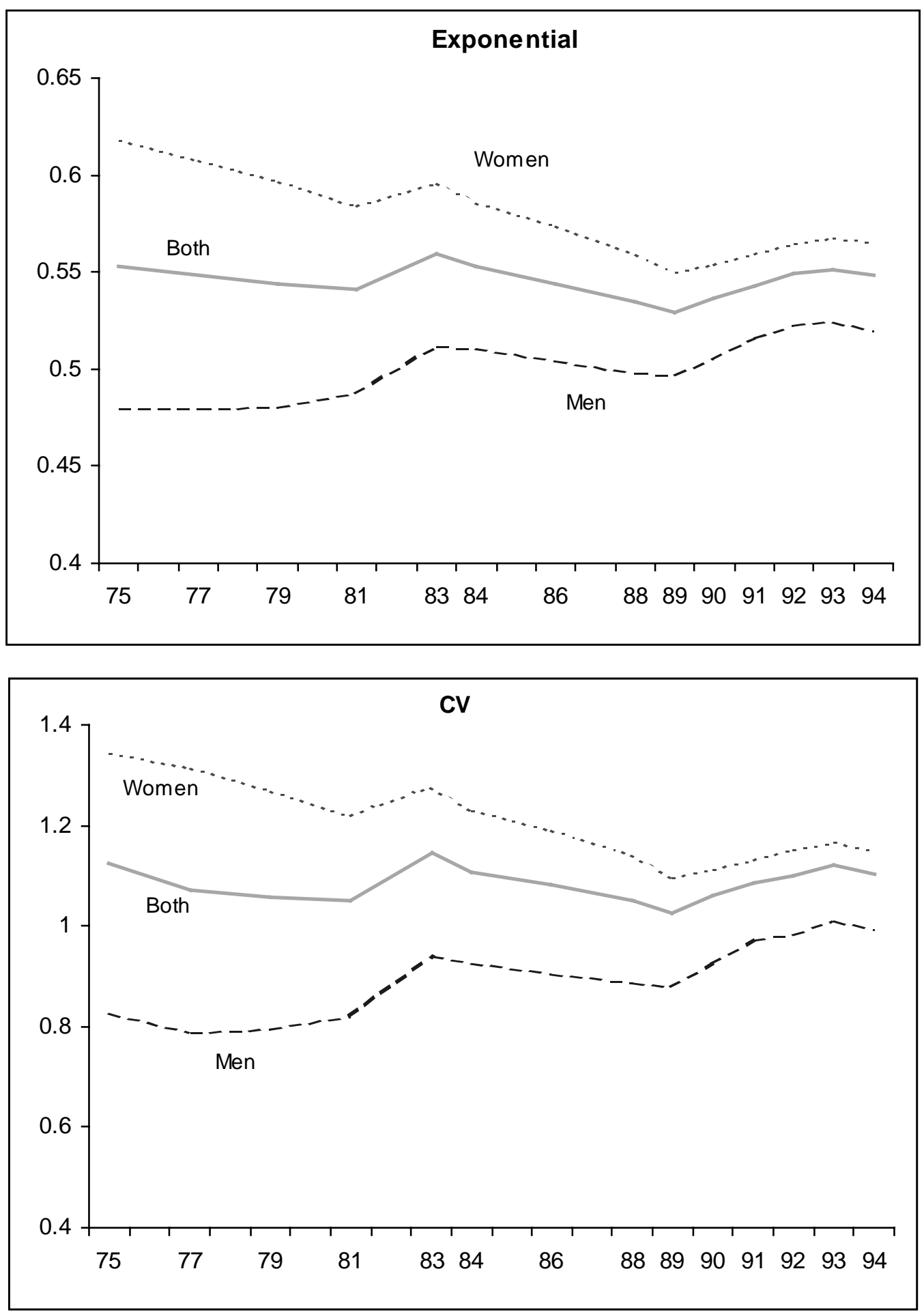
Table A-1: Gini Coefficent, 1975-1995, Paid Employees

\begin{tabular}{|c|c|c|c|}
\hline Year & Men and Women & Men & Women \\
\hline 1975 & 0.396 & 0.339 & 0.396 \\
1981 & 0.403 & 0.347 & 0.413 \\
1984 & 0.422 & 0.386 & 0.421 \\
1986 & 0.418 & 0.380 & 0.417 \\
1988 & 0.418 & 0.378 & 0.417 \\
1989 & 0.408 & 0.374 & 0.403 \\
1990 & 0.417 & 0.384 & 0.412 \\
1991 & 0.420 & 0.394 & 0.413 \\
1993 & 0.428 & 0.405 & 0.424 \\
1994 & 0.423 & 0.400 & 0.416 \\
1995 & 0.419 & 0.395 & 0.419 \\
\hline
\end{tabular}

Table A-2: Regressing the Unemployment Rate on a Time Trend

\begin{tabular}{|c|c|c|c|c|c|c|}
\hline & Atlantic & Quebec & Ontario & $\begin{array}{l}\text { Manitoba/ } \\
\text { Saskatchewan }\end{array}$ & Alberta & $\begin{array}{l}\text { British } \\
\text { Columbia }\end{array}$ \\
\hline Intercept & 10.74 (11.6) & $9.70(8.9)$ & $7.16(5.7)$ & $3.6 \quad(6.4)$ & $6.34 \quad(4.3)$ & $1.82(1.5)$ \\
\hline Time & 0.46 & $0.25(1.1)$ & $-0.03(-0.1)$ & $0.60 \quad(5.2)$ & $0.91 \quad(3.0)$ & $1.07 \quad(4.2)$ \\
\hline Time Squares & $-0.015(-1.7)$ & $-0.007(0.7)$ & $-0.006(0.5)$ & $-0.19(-3.8)$ & $-0.039(-2.9)$ & $-0.038(-3.4)$ \\
\hline & 0.38 & 0.13 & 0.17 & 0.73 & 0.32 & 0.58 \\
\hline \#Observations & 20 & 20 & 20 & 20 & 20 & 20 \\
\hline
\end{tabular}

Appendix Table A-3: Removing the Cyclical Variation from the GINI, by Gender and population Type

\begin{tabular}{|c|c|c|c|c|c|c|}
\hline & \multicolumn{3}{|c|}{ Employed Population } & \multicolumn{3}{|c|}{ Working Age Population } \\
\hline & Men & Women & Both & Men & Women & Both \\
\hline Intercept & $0.422(85.0)$ & $0.460(100.4)$ & $0.456(120.3)$ & $0.547(87.4)$ & $0.670(129.0)$ & $0.621(131.7)$ \\
\hline Unrateresid & $0.0048(2.8)$ & $0.001(0.9)$ & $0.002(2.1)$ & $0.0074(3.4)$ & $0.0036(2.0)$ & $0.004(2.9)$ \\
\hline Atlantic & REF & REF & REF & REF & REF & REF \\
\hline Quebec & $-0.043(-11.1)$ & $-0.052(-14.5)$ & $-0.047(-15.7)$ & $-0.040(-8.1)$ & $-0.025(-6.1)$ & $-0.032(-8.5)$ \\
\hline Ontario & $-0.048(-12.4)$ & $-0.048(-13.3)$ & $-0.043(-14.6)$ & $-0.065(-13.2)$ & $-0.073(-17.8)$ & $-0.064(-17.3)$ \\
\hline $\begin{array}{l}\text { Manitoba/ } \\
\text { Saskatchewan }\end{array}$ & $-0.039(-9.9)$ & $-0.047(-13.0)$ & $-0.035(-11.7)$ & $-0.019(-3.9)$ & $-0.059(-14.5)$ & $-0.035(-9.5)$ \\
\hline Alberta & $-0.034(-8.7)$ & $-0.048(-13.2)$ & $-0.032(-10.7)$ & $-0.055(-11.2)$ & $-0.080(-19.4)$ & $-0.062(-16.5)$ \\
\hline $\mathrm{BC}$ & $-0.056(-14.4)$ & $-0.054(-14.9)$ & $-0.046(-15.5)$ & $-0.065(-13.1)$ & $-0.065(-15.8)$ & $-0.058(-15.6)$ \\
\hline YR76 & REF & REF & REF & REF & REF & REF \\
\hline YR77 & $-0.048(-8.1)$ & $-0.015(-2.7)$ & $-0.025(-5.6)$ & $-0.057(-7.6)$ & $0.042(6.7)$ & $-0.001(-0.2)$ \\
\hline YR79 & $-0.041(-6.5)$ & $-0.005(-0.8)$ & $-0.019(-4.0)$ & $-0.046(-5.6)$ & $0.037(5.6)$ & $0.000(0.0)$ \\
\hline YR81 & $-0.033(-4.8)$ & $-0.003(-0.5)$ & $-0.014(-2.7)$ & $-0.029(-3.4)$ & $0.014(2.0)$ & $-0.004(-0.6)$ \\
\hline YR83 & $-0.007(-1.0)$ & $0.015(2.4)$ & $0.005(1.1)$ & $-0.011(-1.2)$ & $0.020(2.8)$ & $0.007(1.1)$ \\
\hline YR84 & $-0.006(-1.0)$ & $0.002(0.3)$ & $-0.002(-0.4)$ & $-0.005(-0.6)$ & $0.011(1.6)$ & $0.003(0.4)$ \\
\hline YR88 & $0.005(0.7)$ & $0.003(0.5)$ & $0.004(0.9)$ & $0.000(0.05)$ & $-0.015(-2.1)$ & $-0.007(-1.1)$ \\
\hline YR89 & $0.007(1.0)$ & $-0.008(-1.2)$ & $-0.000(-0.1)$ & $0.002(0.19)$ & $-0.026(-3.5)$ & $-0.013(-1.9)$ \\
\hline YR90 & $0.009(1.4)$ & $0.002(0.3)$ & $0.003(0.7)$ & $0.012(1.4)$ & $-0.022(-3.0)$ & $-0.007(-1.1)$ \\
\hline YR91 & $0.012(2.0)$ & $-0.003(-0.5)$ & $0.002(0.5)$ & $0.019(2.5)$ & $-0.024(-3.8)$ & $-0.004(-0.7)$ \\
\hline YR92 & $0.018(2.9)$ & $0.008(1.4)$ & $0.008(1.8)$ & $0.024(3.2)$ & $-0.016(-2.5)$ & $0.000(0.0)$ \\
\hline YR93 & $0.018(2.9)$ & $0.005(0.9)$ & $0.006(1.4)$ & $0.024(3.1)$ & $-0.016(-2.5)$ & $0.001(0.1)$ \\
\hline YR94 & 0.011 (1.9) & $-0.000(-0.0)$ & $0.001(0.2)$ & $0.016(2.2)$ & $-0.018(-2.9)$ & $-0.004(-0.7)$ \\
\hline YR95 & $0.010(1.7)$ & $0.000(0.0)$ & $-0.001(-0.3)$ & $0.025(3.3)$ & $-0.017(-2.7)$ & $-0.001(-0.3)$ \\
\hline \#Observations & 83 & 83 & 83 & 83 & 83 & 83 \\
\hline & 0.91 & 0.85 & 0.89 & 0.92 & 0.94 & 0.89 \\
\hline F Value & 35.5 & 20.4 & 28.0 & 36.8 & 52.7 & 29.5 \\
\hline
\end{tabular}


Appendix Table A-4 : Gini Coefficient, 1975-1995, Total Working Age Population

\begin{tabular}{|c|c|c|c|}
\hline Year & Men and Women & Men & Women \\
\hline 1975 & 0.585 & 0.446 & 0.676 \\
1977 & 0.576 & 0.445 & 0.664 \\
1979 & 0.569 & 0.446 & 0.650 \\
1981 & 0.566 & 0.462 & 0.631 \\
1983 & 0.597 & 0.512 & 0.651 \\
1984 & 0.587 & 0.509 & 0.635 \\
1986 & 0.573 & 0.496 & 0.619 \\
1988 & 0.558 & 0.486 & 0.596 \\
1989 & 0.548 & 0.483 & 0.580 \\
1990 & 0.560 & 0.501 & 0.588 \\
1991 & 0.572 & 0.521 & 0.596 \\
1992 & 0.580 & 0.534 & 0.606 \\
1993 & 0.585 & 0.538 & 0.611 \\
1994 & 0.579 & 0.529 & 0.606 \\
1995 & 0.578 & 0.531 & 0.606 \\
\hline
\end{tabular}




\section{Selected References}

Bar-Or, Y., J. Burbidge, L. Magee and L. Robb (1993). "Canadian Experience-Earnings Profiles and the Return to Education in Canada, 1971-1990." Working Paper No. 93-04, Department of Economics, McMaster University (Hamilton).

Beach, C.M. and G. A. Slotsve (1996). "Are We Becoming Two Societies." C.D. Howe Institute, Toronto.

Beach, C.M. and G.A. Slotsve (1994). "Polarization of Earnings in the Canadian Labour Market." Bell Canada Papers on Economics and Public Policy.

Beaudry, P. and D. Green (1996). "Cohort Patterns in Canadian Earnings and The Skill Biased Technical Change Hypothesis." Discussion paper No. 97-03, Dept. of Economics, University of British Columbia.

Benley, T.F. (1994). “A Field Study on Downward Wage Rigidity.” Unpublished Paper, York University.

Betcherman, G. and R. Morissette (1994). "Recent Youth Labour Market Experiences in Canada." Ottawa: Statistics Canada, Analytical Studies Branch Research Paper No. 63.

Bound, J. and G. Johnston (1992). "Changes in the structure of wages in the 1980s : an evaluation of alternative explanations." American Economic Review.

Burbidge, J., L. Magee and L. Robb (1993). “On Canadian Wage Inequality: The 1970s and 1980s.” Working Paper No. 93-07, Department of Economics, McMaster University (Hamilton).

Burtless, G. (1990). "Earnings Inequality Over the Business and Demographic Cycles." In Gary Burtless ed. A Future of Lousy Jobs?, Washington, DC: The Brookings Institution.

Card, D. and R. Freeman (1994). "Small Differences that Matter: Canada Vs. the United States." In Working Under Different Rules, Freeman, R.B., Editor.

Davis, S.J. (1992). "Cross-Country Patterns of Change in Relative Wages." National Bureau of Economic Research Working Paper No. 4085.

Economic Council of Canada (1991). Employment in the Service Economy. Ottawa: Supply and Services Canada.

Freeman, R.B. and L.F. Katz (1994). "Rising Wage Inequality: The United States VS. Other Advanced Countries." In Working Under Different Rules, Freeman, R.B., Editor.

Freeman, R.B. and K. Needels (1991). "Skill Differentials in Canada in an Era of Rising Labor Market Inequality." National Bureau of Economics Research Working Paper No. 3827.

Hall, R.E. (1995). “Lost Jobs." Brookings Paper on Economic Activity. 
Juhn, C., K.M. Murphy and H.T. Topel (1991). "Why Has the Natural Rate of Unemployment Increased Over Time?" Brookings Papers on Economic Activity.

Kapsalis, C., R. Morissette and G. Picot (1997). "The Return to Education and the Increasing Wage Gap Between Young and Older Workers." Ottawa: Statistics Canada, Analytical Studies Branch Research Paper (Forthcoming).

Katz, L.F. and K.M. Murphy (1992). "Changes in Relative Wages, 1963-1987: Supply and Demand Factors." Quarterly Journal of Economics, 107(1): 35-78.

Kuhn, P. and A.L. Robb (1996). "Shifting Skill Demand and the Canada-U.S. Unemployment Gap." Economic Dept., McMaster University, Paper Presented to the CERF/CSLI Conference on Canada-U.S. Unemployment Gap, Ottawa, February 1996.

Lemieux, T. (1993). " Union and Wage Inequality in Canada and the United States." In D. Card and R. Freeman (eds). Small Differences that Matter, Chicago: University of Chicago Press for NBER.

Morissette, R. (1995). "Why Has Inequality in Weekly Earnings Increased in Canada?" Ottawa: Statistics Canada, Analytical Studies Branch Research Paper No.80.

Morissette, R. and C. Bérubé (1996). "A Longitudinal Analysis of Earnings Inequality in Canada." Ottawa: Statistics Canada, Analytical Studies Branch Research Paper No. 94.

Morissette, R., J. Myles and G. Picot (1994). "Earnings Inequality and the Distribution of Working Time in Canada." Canadian Business Economics, Vol 2, no. 3, Spring 1994, 3-16.

Murphy, K.M. and F. Welch (1992). "The Structure of Wages." Quarterly Journal of Economics 107(1), 284-326.

Myles, J., G. Picot and T. Wannell (1988). "Wages and Jobs in the 1980s: Changing Youth Wages and the Declining Middle." Ottawa: Statistics Canada, Analytical Studies Branch Research Paper No. 17.

OECD (1996). "Earnings Inequality, Low-Paid Employment and Earnings Mobility." 1996 Employment Outlook, July.

Picot, G. (1996). "Earnings Inequality, Working Time and Wages Among Men and Women." Presented at the KILN Conference, McMaster University, mimeo, Ottawa: Statistics Canada, Business and Labour Market Analysis Division.

Richardson, D.H. (1994). "Changes in the Distribution of Wages in Canada, 1981-1992." Discussion Paper No. 94-22, Dept. of Economics, University of British Columbia.

Riddell, W.C. (1993). "Unionization in Canada in the United States: A Tale of Two Countries." In David Card and Richard B. Freeman eds. Small Differences that Matter: Labor Markets and Income Maintenance in Canada and the United States (The University of Chicago Press). 
Wolfson, M.C. and J. Foster (1993). "Inequality and Polarization Concepts and Recent Trends." Paper Presented at the Winter Meetings of the American Statistical Association, Ft. Lauderdale, January.

Wolfson, M.C. and B.B. Murphy (1998). "New Views on Inequality Trends in Canada and the United States." Monthly Labor Review, April 1998.

Wolfson, M. (1996a). "Three Views on Income Equity." A talk given at the Conference on Globalization, sponsored by the Robarts Centre, York University.

Wolfson, M. (1996b). "Divergent Inequalities - Theory and Empirical Results." Mimeo, Ottawa: Statistics Canada, Analytical Studies Branch.

Zyblock, M. (1996a). "Individual Earnings Inequality and Polarization: An Explanation into Population Sub-Group Trends in Canada, 1981-93." Ottawa: Human Resources Development Canada, Applied Research Branch, Mimeo.

Zyblock, M. (1996b). "Why is Family Market Inequality Increasing in Canada?" Ottawa: Human Resources Development Canada, Applied Research Branch Working Paper W-96-11E. 